June 1997

\title{
Molecular and Cellular Biology of Prostate Cancer
}

El-Nasir Lalani

Aga Khan University, elnasir.lalani@aku.edu

Marc Elie Laniado

Hammersmith Hospital

Paul David Abel

Hammersmith Hospital

Follow this and additional works at: http://ecommons.aku.edu/ pakistan_fhs_mc_pathol_microbiol

Part of the Male Urogenital Diseases Commons, Oncology Commons, Pathology Commons, Reproductive and Urinary Physiology Commons, and the Urology Commons

\section{Recommended Citation}

Lalani, E., Laniado, M. E., Abel, P. D. (1997). Molecular and Cellular Biology of Prostate Cancer. Cancer and Metastasis Reviews, 16(1), 29-66.

Available at: http://ecommons.aku.edu/pakistan_fhs_mc_pathol_microbiol/375 


\title{
Molecular and cellular biology of prostate cancer
}

\author{
El-Nasir Lalani', Marc Elie Laniado ${ }^{2}$ and Paul David $\mathrm{Abcl}^{2}$ \\ Department of 'Histopathology and ${ }^{2}$ Surgery, Royal Postgraduate Medical School, Hammersmith Hospital, \\ rondon WI2 ONN, UK
}

Key words: prostatic neoplasms, cytogenetics, oncogenes, growth factors, ion channcls

\begin{abstract}
Prostate cancer is an enigmatic disease. Although prostatic-intracpithelial neoplasia appears as early as the third decade and as many as $80 \%$ of 80 year old men have epithelial cells in their prostate that fit the morphological criteria for cancer, only about $10 \%$ of men will ever have the clinical disease and less than $3 \%$ will die from it. There have been no significant proven interventions which have altered the natural history of the disease since hormone down regulation was introduced in the 1940s and new research has been poorly supported. There is however an urgent need to develop new criteria to distinguish those patients with localised disease who will benefit from intervention from those that do not require it or who will have occult extra prostatic metastases. Similarly, there is an urgent need to develop new treatments for those in whom the discase is extra-prostatic and therefore incurable by conventional treatments. 'This review covers the latest developments in epidemiology, cellular and molecular biology including new arcas such as ion channcls in the field of prostate cancer.
\end{abstract}

\section{Prostate cancer - clinical perspectives}

Prostate cancer (PC) is the commonest cancer in men and the second commonest cause of cancer death in the western world [1]. 'There were an estimated quarter of a million cases world-wide in 1985 [2] and the incidence appears to be incrcasing [3]. In the carly 1990's, it was predicted that PC would account for 35,000 deaths annually in the European Community [4] and 38,000 in the USA [5] where it presents a lifetime risk of almost $10 \%$ [6]. More recently, it has been estimated that in 1996 there will be 317,000 newly diagnosed $P C$ cases and 41,400 deaths in the USA compared to the 1995 figures of 244,000 and 40,400 respectively [7]. The difference between incidence rates and deatl rates is striking but the increase in the latter is at least in part because of demographic trends, with many more men surviving to an older age when $P C$ is more frequent (1600:100000 in black American 80 year olds compared to less than 2:100000 in 40 year olds [3]). In contrast, the rise in incidence rates is almost certainly a consequence of the introduction of serum assays for prostate specific antigen (PSA) as well as more digital rectal examinations, transrectal ultrasound examinations and prostatic needle biopsies being performed in the clinic.

Whether PSA screening will enable the identification of cancers at a time when they will be curable is contentious [8-10]. This is probably because screening reveals many men with PCs that would never become clinically significant. Screening also finds men with PC which seem localised but with occult metastases which become apparent after local treatment (Table 1). Neither group would benefit from such treatment and it remains impossible, at the current linte, to distinguish one group from another. The extent of the controversy can be demonstrated by one study which postulated that should all men in the UK be screened once and hall the detected cancers treated with radical surgery, the probable operative mortality would exceed the an- 
nual death rate from $P C$ in the same population [11]. However, randomised trials of screening are underway, for example initiated by the National Cancer Institute [12] whose demanding protocol may cost US\$89 million.

\section{Aetiology of prostate cancer}

There is evidence that differing incidences of PC are influenced by cpigenetic factors. The increased incidence of clinical cancer in Japancse immigrants to the USA within 2 generations offers one such example [13]. Dict is believed to be relevant, with the predominantly vegetarian dict in Asia exerting a protective role [14]. Total fat consumption has been dircctly related to the risk of advanced $\mathrm{PC}$, cspecially saturated fat as well as red meat and high caloric intake [15]. Other aetiological factors include vitamins $\mathrm{A}$ and D. Vitamin E is suggested to have a protective effect $[16,17]$. Employment in agricultural occupations appears to have a positive association with PC $[18,19]$. Even prenatal exposure to pregnancy hormones and growth factors may influence prostate carcinogenesis [20].

\section{Management of prostate cancer}

Whitmore has asked 'Is cure possible in those for whom it is necessary, and is cure necessary in those for whom it is possible?' [21]. There is no doubt that large numbers of patients require effective treatment for their discase, whether localised or extraprostatic. However, there have been no major changes in mortality and no major advances in treatment since the introduction of androgen down-regulation won the Nobel prize for Huggins in the early 1940s. There has however recently been a huge rise in the numbers of radical prostatectomies performed, in parallel with the current rise in diagnosis. The first description of radical surgery appeared over 90 years ago [22] and despite this, there is still no conclusive proof that it is of benefit \{23|. Some commentators have actually described the use of radical prostatectomy as "probably the longest running phase 1 cancer trial in the history of medicine' [24].

\section{Clinically significant and latent cancer}

Part of the problem in managing PC lies with the fact that there is a 'latent" form of the disease that is cqually prevalent in communities throughout the world [25]. Latent cancer is generally an incidental finding, usually identified in post-mortem studies or in prostates removed surgically for apparently benign disease or more recently following PSA testing and imaging directed stereotactic biopsy. Latent PC is by definition small, generally well differentiated and the clinical behaviour is usually indolent. This cancer may be found as early as the third decade and has been reported in about $30 \%$ of fifty year olds and up to $80 \%$ of 80 year olds at post-mortem [26]. The incidence of latent cancer occurs equally across countries and racial groups. This is in sharp contrast to clinically important cancer which is rare in Asia (1:100000) but reaches epidemic proportions in the west, the highest rates being reported in Afro-Caribbean men in the USA (sec above) [3].

Now genotypic and phenotypic markers are therefore urgently needed to classify the disease accurately and guide management. The underlying molecular and cellular mechanisms governing initiation and promotion of the malignant and metastatic phenotypes are unknown in $\mathrm{PC}$, although some clues may be gained from the study of other

Table l. Clinical manifestations of prostate cancer

'Localised' prostate cancer

Latent (clinically unimportant)

Clinical without Incal invasion or metastases (curable)

Clinical with undetected local occult metastases (incurable)
Extraprostatic prostate cancer

Locally advanced without metastases

Locally advanced with metastases

Metastases but localised primary 
cancers. Of particular relevance is the need to investigate factors governing hormone-regulation which may be specific to PC and the biology of the stromal proliferation in metastatic disease which governs the clinical manifestations. This may lead to rational strategies for cancer management rather than the currently unobtainable (and perhaps unnecessary) goal of cancer 'cure'/eradication.

\section{Prostate cancer - biological aspects \\ Anatomical structure of the prostate gland}

The prostate is a pear shaped glandular organ weighing up to 20 grams in the young adult male. It is enveloped by a capsule which is composed of an inner layer of smooth muscle and an outer fibrous capsule [27]. The prostate comprises three distinct zones: the peripheral (PZ), central (CZ) and transition zones (TZ) $[28,29]$. The PZ is the largest zone (70\% by volume) and is the commonest sitc for prostatic intraepithelial neoplasia (PIN) and adenocarcinomas which both arise from peripheral ducts and acini [30]. The $\mathrm{CZ}$, which encircles the ejaculatory ducts, occupies approximately $25 \%$ of the volume of the prostate. The remaining $5 \%$ is formed by the TZ which is the primary site for nodular hyperplasia and the rare large duct carcinomas. Collectively the $\mathrm{PZ}$ and $\mathrm{CZ}$ are often referred to as the outer or cortical prostate, whereas TZ and the anterior fibromuscular stroma are known as the inner or periurethral prostate. In a normal prostate it is difficult to delineate the threc zones histologically.

The glandular components (acini and ducts) of the prostate are composed predominantly of two types of epitlelial cells: secretory and basal. These are interspersed with occasional neuroendocrine (NE) cells. These cell types can be phenotypically distinguished and are described below (Table 2).

\section{Luminal (secretory) cells}

Prostatic growth and differentiation is dependent on testicular derived androgenic hormones and on complex and as yet poorly understood epithelialmesenchymal interactions. The glandular component of the prostate is composed of large (primary, major, excretory) and peripheral (secondary, $\mathrm{mi}$ nor) ducts. The acini and ducts contain secretory, basal and neurocndocrine cells. The luminal cells of the gland are secretory in mature and phenotypically express keratins 8 and 18 , prostatic acid phosphatase (PAP), prostate specific antigen (PSA) and the androgen receptor (Table 2) [31-33]. They require androgens for maintenance of their differentiated function [34]. Adenocarcinomas of the prostatc are considered to differentiate towards secretory cells as they express heterogeneously phenotypic markers typical of the secretory cell populations.

\section{Basal cells}

These are considered to be multi-potential in nature giving rise to all epithelial lineages in normal, hyperplastic and neoplastic prostates [35]. They scparate the secretory cells from the bascmenil membranc and express high molecular weight cytokeratins reactive with the monoclonal anti-keratin antibody 34betat12 (lable 2) [36]. 'I his antibody is specific for keratins $1(68 \mathrm{kDa}), 5(58 \mathrm{kDa})$, $10(56.5 \mathrm{kDa})$ and $14(50 \mathrm{kDa})$ which are characteristically found in complex epithelia [36]. It has been

Table 2. Phenotypic markers of glandular cell types of normal human prostate

\begin{tabular}{llll}
\hline Phenotypic markers & Sccretory/luminal cell & Basal cell & Neuroendocrine cell \\
\hline PSA & Yes & No & Ycs \\
PAP & Yes & No & No \\
Androgen receptor & Yes & Focal & No \\
Cytokerstins & 8,18 & $5,14(\mathrm{H} \mathrm{Mw} \mathrm{Cks})$ & $?$ \\
MUC1 & Yes & No & No \\
Chromogranin (A/B) & No & No & Yes \\
Smooth muscle actin & No & No & No \\
S-100 & No & No & No \\
\hline
\end{tabular}


used to help distinguish well differentiated adenocarcinomas (in which basal cells are absent) from benign conditions that simulate it such as adenosis, sclerosing adenosis, basal ccll hyperplasia, atrophy, benign prostatic tissue with radiation atypia, and clcar cell cribriform atypia [37-41]. Normal prostatic basal cells do not express PSA or PAP $[42,43]$. They have been shown to express the androgen receptor focally [44, 45]. Neither basal nor sccretory cells express S-100 protein or smooth muscle actin helping to distinguish them from neuronal or smooth muscle cells.

\section{Neuroendocrine ( $N E$ ) cells}

These cells are present in all zones of the prostate although thcy are more abundant in the periurethral and ductal regions [46]. NE cclls are found in the glandular component of the prostate among the secretory and basal cells [47]. They sccrete a variety of biogenic amines (chromogranin A and B, secretogranin II, ncurone specific enolase and serotonin) which are found in most prostatic NE cells (Table 2) $[48,49]$ or peptide hormones (somatostatin. calcitonin, bombesin) which are secreted by some of the cells [50]. They co-express PSA, suggesting an origin common with the secretory cells [ 48$]$ but they do not express the androgen reccptor (Table 2) [51]. For a recent review on NE cells readers are referred to articles by Noordzij and di Sanl'Aguese $[52,53]$.

\section{Prostatic stroma}

This is a complex mixture of smooth muscle cells, fibroblasts, blood vessels, nerves and the intervening extra-ccllular matrix. Normal prostatic development is critically dependent on complex and as yet poorly understood epithelial-mesenchymal in1eraction [54-58], and there is a highly complex dynamic interaction between tumour cells and the in- duced (dcsmoplastic) fibroblast population which may come to dominate some prostatic cancers.

Benign prostatic hyperplasia $(B P H)$. Other conditions commonly co-exist with $\mathrm{PC}$ and are often found in prostate specimens. $\mathrm{BPH}$ is the most frequent benign condition found in the prostate and there are some similarities between $\mathrm{PC}$ and $\mathrm{BPH}$ (Table 3 ). Both require androgenic stimulation, show increased prevalence with age (although PC usually occurs $15-20$ years later) may co-exist and may respond to androgen deprivation. Most PCs arise in prostates which already have $\mathrm{BPH}$. In $10 \%$ of elective TURPs (transurethral resection of the prostate) for symptoms of bladder outflow obstruc tion clinically secondary to $\mathrm{BPH}$, there is associated PC [59]. However, BPH is not a premalignant lesion nor is it a precursor of $\mathrm{PC}$.

Prostatic intraepithelial neoplasia $(P I N)$. This is considered the most likely precursor of invasive carcinoma, but studies have not determined conclusively whether PIN remains stable, regresses or progresses $[59,60]$. It is characterised by proliferation of the luminal epithelium within pre-existing acini and ducts, with cytological atypia, including nuclear pleomorphism and nucleolar enlargement. By definition, there is no basement membrane invasion. Grading (I, II, III) depends on the severity of the following cytological and nuclear changes: (a) cellular crowding and stratification, (b) nuclear enlargement and pleomorphism, (c) chromatin paltern and nucleolar appearance. PIN is currently subdivided into two categories: low grade (PIN I) and high grade (PIN II and III) [60].

PIN has been reported to be present in greatcr than $85 \%$ of cases of PC [59]. Inter-observer variability for PIN grading is common, especially of low

Table 3. Similarilics and differences between $\mathrm{BPH}$ and $\mathrm{PC}$

\begin{tabular}{lll}
\hline & BPH & Prostate cancer \\
\hline Common sites ol occurrence & rransition zonc & periphcral ronc and transition zone \\
Prevalence with age & increases & increases (lags by 15-20 ycars) \\
Androgens & required for growth & requircd for growth \\
Androgen deprivation & can decrease growth & can decrease growth \\
premalignant potential & none & \\
\hline
\end{tabular}


grade and this may account for the difference in reported associations [61]. In a recent study with patients that were re-biopsied following a diagnosis of PIN, $13 \%$ with low grade PIN and $48 \%$ with highgrade PIN had frank cancer in the subsequent biopsy [62]. Several studies suggest that PIN predates PC by some 10 years with low grade PIN first appearing in men in the third decade [63-65]. In prostates containing both PIN and PC there is a good degree of concordance in the DNA ploidy pattern of both lesions [66-68]. These observations suggest that high grade PIN may have a high predictive value as a marker for PC and some clinicians believe that patients with PIN should be closely monitored to include follow up biopsies. However, the identification of PIN should not influence or dictate therapeutic decisions [60] and there is a risk of inducing 'cancer-phobia' in such patients.

\section{Molecular pathology}

Advances made in molecular biology have had a major impact on the practice of surgical pathology [69-74] and the role of the academic pathologist. Many of the molecular biology techniques are being adapted for use on fixed paraffin embedded tissues. Microdissection has increased both specificity and sensitivity for the analysis of DNA, mRNA and protein in samples containing a heterogeneous population of cells. Fixed material is sometimes suboptimal for analysis and the availability of snap-frozen or specially fixed tissues is a major resource in academic pathology institutes.

Pathologists are increasingly being involved in the translation of techniques developed in pure research laboratories to routine use in diagnostic pathology. The pathologist is an integral momber of multidisciplinary research teams interpreting gross and microscopical appcarances in human diseases and animal models (e.g. transgenic and gene knockout mice). They are also important in assessing expression patterns at protein and mRNA level of specific gencs and their alterations in differing disease states. The following sections illustrate the interface between basic sciences and clinical research in relation to $\mathrm{PC}$.

\section{Material}

\section{Human tissue}

Most prostatic specimens result from trans-urethral resection of prostate (TURP) or radical prostatectomy (RP). RP tissue includes the whole prostate whereas TURP selectively samples the TZ, which is pathologically enlarged by the process of $\mathrm{BPH}$, rather than the whole gland. The biology and clinical behaviour of cancer found in TURP specimens is therefore not necessarily the same as cancer found in RP specimens. It is usually of lower Gleason grade, with less frequent capsular penetration and lymph node metastasis [59]. There is also a major problem in obtaining samples of metastatic dis-

Table 4. Main distinguishing features of human PC cell lines

\begin{tabular}{|c|c|c|c|}
\hline & LNCaP & DU-145 & $\mathrm{PC}-3$ \\
\hline Tumourigenicity in new mice & + & + & ++ \\
\hline Metastatic polential & - & \pm & $+[395]$ \\
\hline Hormonal sensitivity & + & - & - \\
\hline Biomarkers & $\begin{array}{l}\text { PSA. PSM, prostatic } \\
\text { acid phosphatase, } \\
\text { prostatic inhibitory } \\
\text { peptide, cytokeratins } \\
8,18[396-399]\end{array}$ & $\begin{array}{l}\text { PS A and PSM } \\
\text { negative [396- } \\
399]\end{array}$ & $\begin{array}{l}\text { Prostatic inhibitory } \\
\text { peptide and prostatic } \\
\text { acid phosphatase } \\
\text { positive, PSA } \\
\text { negative [396-399] }\end{array}$ \\
\hline Origin & $\begin{array}{l}\text { supraclavicular } \\
\text { lymph node in a } \\
\text { paticnt with hormonally } \\
\text { sensitive cancer }\end{array}$ & brain metastasis & $\begin{array}{l}\text { bone marrow } \\
\text { metastasis in patient } \\
\text { with hormone- } \\
\text { independent PC }\end{array}$ \\
\hline
\end{tabular}


easc. Some of these problems may be circumvented by PCR amplification of fine needle aspiration biopsy, where a thin needle is used to extract a few cells from a particular lesion, it will not be possible to evaluate the rclative contribution of the malignant epithelial, entrapped benign, and stromal cells from any one sample. It is important to appreciate the differences in interpretations possible with results obtained from cells and tissues obtained through a wide range of surgical procedures.

\section{Cell lines}

Much of the understanding of the pathogenesis of $\mathrm{PC}$ arises from the study of cell lines. There are 3 principal human PC cell lines (Table 4) and, multiple rat cell lines derived from the original rat Dunning tumour as well as other less well known cell lines. [75-78].

The LNCaP cell line was derived from a supraclavicular lymph node from a patient with hormone-refractory PC [79]. LNCaP cells express cytokeratins $(8,18)$ which are also expressed by prostatic luminal cells (see above). This cell line produces four biomarkers of the prostate: PSA, PAP, prostate-specific membrane antigen (PSM) and prostatic inhibitory peptide (PIP) [81, 82]. In addition, these cells express a high-affinity mutated (codon 868, Thr $\rightarrow$ Ala) androgen-receptor (AR), which is blocked by bicalutamide but behaves idiosyncratically with other antiandrogens (cyproterone acetate and flutamide). These latter act as agonists and stimulate proliferation [83, 84]. Althouglı LNCaP tumours grow in nude mice and are hormonally responsive, they do not metastasise [85].

The PC-3 cell line, which was derived from a human bone marrow metastasis, does metastasise when injected subcutaneously into nude mice in about $30 \%$ of cases [86]. It expresses PSA as well as PIP and PAP, but not PSM $[82,87]$. It does not produce an androgen receptor and is not hormonally responsive. These differences from the $\mathrm{LNCaP}$ cell line may reflect tumour dedifferentiation and rescmble high grade and advanced stage human $\mathrm{PC}$. A highly invasive subline of PC-3 cells, PC-3-ML has been developed which is considerably more invasive in vivo [88].

\section{Microdissection}

The application of molecular markers to pathological specimens is critically dependent on optimised procedures and the proportion of the sample with the feature of interest, e.g. a specific genetic mutation. Independently arising tumours vary in the combinations of genetic changes they contain and in the precise malignant phenotype they express.

$\mathrm{PC}$ is characterised by a remarkably low frequency of alterations in genes known to be associated with other malignancies such as ras, myc, erb $B-2$, $p 53$, and $R B I$ [89]. To date, no specific oncogenes or tumour suppressor genes (TSGs) have been conclusively correlated with PC initiation or progression. Given the heterogencity of biopsies, and the infiltrative nature of tumours a low frequency of detcctivin could stem from dilution of ncoplastic DNA by stromal and/or entrapped non-neoplastic cellular elements. An important consideration in molecular analysis of tissues is the minimisation of the unavoidable contamination of tumour biopsies by such clements $[90,91]$. Berthon and colleagues suggest that at least $20 \%$ of total DNA from a tumour sample needs to be mutated to score positively in PCR/SSCP analysis. They further suggest that when only one allele is affected greater than $40 \%$ of cells present within the specimen used for DNA extraction must be from the tumnur [92]. Therefore the use of precise microdissection techniques is extremely important in analysing molecular markers from fresh and archival matcrial.

\section{Methods}

Molecular genetic techniques have advanced over the last decade to a point where they can be used on routine clinical material. For those readers who may not be familiar with some of these techniques the following sections briefly describe methods with emphasis on those applicable to archival material where the greatest clinical reserve lies.

\section{Detection of point mutations}

There arc at least threc methods which can be used 
tor the detection of point mutations in surgical specimens.

Allele-specific oligonucleotide hybridisation. This method is based on the principle that a duplex of oligonucleotides with even one mismatch is unstable [93]. Two steps are involved: (a) extraction of DNA from tissuc samples and its amplification by the polymerase chain reaction (PCR) and (b) screening of the amplificd DNA on filters with radio-labelled synthetic oligomers whose sequences correspond to possible amino acid substitutions. Brielly, DNA is extracted from formalin-fixed paraffin-embedded tissue. Formylation of nucleic acids produces Schiff bases on free amino groups of nucleotides, and exposure of nucleo-proteins to formaldehyde results in the formation of crosslinks between proteins and DNA [94]. These processes are reversible in aqueous solution, implying that DNA can be recovered from formalin-fixed tissue. DNA extracted from fixed tissucs is not intact, but it is double stranded, cleavable with restriction endonucleases, can be hybridised with labelled probes and amplified by using PCR. If available, DNA extracted from fresh or frozen tissues is more suitable for a variety of standard molecular techniques $[95,96]$. Following extraction and PCR amplification of the DNA it is immobilised to filters and hybridised with an oligonucleotide which spans the mutation of interest.

Direct sequencing of DNA amplified by $P C R$. In vitro amplification of DNA using PCR and subsequent direct sequencing of the product is an alternate approach to the detection of mutations [93].

\section{Single strand conformational polymorphism} (SSCP) analysis. In this method, the DNA sequences of interest are amplified and labelled by PCR using labelled primers or labelled nucleotide [97]. Most single base pair changes in fragments up to 200 bases can be detected as mobility shifts by SSCP analysis (e.g. ras point mutation) [98]. The limitation of this technique is that the position and exact nature of the mutation can not be detcrmined. However, SSCP is a useful technique for screening point mutations as it is simple, fast and efficient. When gel shifts suggest mutations, other methods such as direct sequencing must be used to determine the base substitution.

\section{Detection of gene amplification}

Gene amplification can be detected in formalinfixed paraffin embedded tissue by dot-blot analysis. On fresh or frozen samples Southern blot analysis is preferable $[95,96]$. Amplification is determined by comparing the signal intensity by densitometer with parallel samples hybridised with a reference single copy gene and the gene of interest.

\section{Detection of loss of heterozygosity ( $\mathrm{LOH})$}

DNA restriction enzymes recognise specific sequences in DNA and by catalysing endonucleolytic clcavages, create fragments of ccrtain lengths which are displayed by agarose gel electrophoresis. Individual variability in the lengths of a particular restriction fragment - restriction fragment length polymorphism (RFLP), result from a variety of genetic differences. Change in a single base pair could result in either loss or formation of cleavage sites. Insertion or deletion of DNA may also alter the size of the fragments. In either case the altered mobility of restriction fragments subjected to gel electrophoresis can readily be detected by Southern blotting and hybridisation with a labelled DNA probe which recognises an adjacent or linked DNA sequence. 'This method has been applied to genetic linkage analysis and also to unravel specific chromosomal deletions in PC identifying putative TSGs or PC genes and can be applied to extracted DNA from fresh or archival material. Using this technique it is possible to build up a picture of the genome and to identify which chromosomal regions are deleted or are rearranged in tumour cells of individual patients. The significance of the consistent loss of specific regions of genetic information from the genomes of tumour cells of particular histological type is now appreciated as such areas may contain as yet unrecognised TSGs. The characterisation of regions consistently lost forms the first step in localising such genes.

In situ hybridisation (ISH)

In situ hybridisation (ISH) was first described by Gall and Parduc in 1969 [99]. It enables topographic 
detection of nucleic acids (DNA or RNA) in cellular material (lissues and cell lines). One of the major advantages of ISH over solution filter hybridisation techniques (Southern/Northern blotting or gel electrophoresis) is the precise identification of specific cells within a heterogencous population. Considerable information regarding the structure and function of cells within pathological lesions can be derived by this means. Combining ISH and immunocytochemistry provides the final link between transcription and translation.

The method employed for a given experiment critically depends on:

(a) the target nucleic acid (DNA or RNA)

(b) sensitivity and

(c) spccificity desired.

DNA is relatively stable and is preserved in tissues even after routine fixation, unlike mRNA which is labile and highly susceptible to endogenous enzymatic degradation. Detection of mRNA requires different conditions (collection, storage, detection) to those of DNA. High sensitivity is necessary where sequences of low abundance are to be detected. Conversely, there are situations where only low sensitivity detection systems are desirable e.g. detection of specific repetitive sequences. The speci ficity of ISH is detcrmined by the hybridisation and post hybridisation washes. The manipulation of these conditions provides flexibility and allows the detection of sequences related but not identical to the probe used. This is useful for example in determining viral subtypes. For a detailed description of DNA and RNA in situ hybridisation, readers may refer to specialist texts [100].

\section{Fluorescent in situ hybridisation (FISH)}

Cancers are characterised by genctic instability which may manifest as:

(a) abnormalitics of chromosome number,

(b) gross delctions,

(c) translocations and

(d) gene amplifications.

Characteristic chromosome aberrations have been described in a wide range of tumours and some of these may serve as potential diagnostic or prognostic markers $[101,102]$. Conventional cytogenetic analysis requires viable cells for the production of meta- phase spreads followed by chromosome slaining and visualisation for specific abnormalities. This is a slow and tedious process. Furthermore, many cancers do not grow in culture or are refractive to metaphase analysis rendering this approach inapplicable.

FISH provides a simple fast and reliable means for assessing genetic instability in cancer. It is possible to identify either entire chromosomes or rcgions smaller than a single gene. In addition, interphase cells can be used eliminating the need to culture cells and often touch preparations are adequate. FISH based analysis of chromosome aneusomy can be accomplished with interphase nuclei using fluorophore-labelled probes to highly repetitive centromeric regions. As the centronleric region of the chromosome remains condensed throughout the cell cycle, hybridisation to this region appcars as a small spot within the interphase nucleus. Multiple chromosomal aberrations can be identified using multicolour-multitarget FISH [103]. As an example, one study from the Mayo Clinic examined paraffin embedded sections of PCs for chromosome ancusomy in two groups of paticnts: those who survived less than 3 years and those who survived greater than 5 ycars after initial diagnosis. All of the patients had either $T_{2} N_{0} M_{0}$ or $T_{3} N_{0} M_{0}$ stage cancer. A high correlation between chromosome 7 trisomy and poor survival was reported [104].

\section{Comparative genomic hybridisation (CGII)}

$\mathrm{CGH}$ provides a genomic fingerprint at a megabase level of resolution. Experimentally total DNA is extracted from normal tissue and from tissue with a neoplasm. Both DNA samples are labelled with a distinct fluorophore. The two labelled samples are mixed and hybridised to normal metaphase spreads. If the normal DNA was labelled with a green fluorochrome and the tumour DNA with a red fluorochrome, when they are present in a 1:1 ratio this results in a yellow signal. However, if there is a deletion in the tumour (no red label) there is green fluorescence. Gene amplification (e.g. androgen receptor) will result in multiple copies of red DNA and this region will therefore appear red. It is possible to computer map (utilising incremental colour ratios) areas of deletion and amplification. 
Polymerase chain reaction $\left(Y^{\prime} C R\right)$ and reverse transcriptase PCR (RT-PCR)

The polymerase chain reaction was first described by Mullis and collcagues at Cetus corporation [105]. The subsequent inclusion of a thermally stable DNA polymerase [106] greatly facilitated its application and since its introduction, its uses and users have expanded significantly both in research and clinical applications. PCR allows specific in vitro enzymatic replication of nucleic acids directed by specific synthetic oligonucleotide primers. The PCR cycle consists of heat denaturation of the DNA followed by primer annealing and DNA synthesis. Primers are oriented to facilitate overlapping replication resulting in exponential increase in nucleic acids. Primers, which are in great excess, hybridise to opposite strands. The original target sequence and the synthesised PCR products serve as PCK substrates resulting in an exponential increase in the DNA sequence of interest. By using PCR it is possible to detect a single copy of a gene present in 100,000 cells compared to Southern blot which can detect one copy in 100 cclls. This is a highly sensitive and specific technique. On average a PCR reaction may take $2-4$ hrs depending on the sensitivity required, each cycle taking 2-5 minutes. There are on average $25-50$ cycles [106]. PCR has at least two critical advantages: high sensitivity and short assay time. It can be readily applied to microdissected pathological specimens.

RNA is more readily degraded than DNA and its detection is more difficult. However, from optimally preserved samples, RNA can be extracted and PCR amplified after conversion to cDNA by the enzyme reverse transcriptase. This method is known as RT-PCR [106].

\section{Molecular genetics of PC initiation, progression and metastasis}

Studies on PC have been hampered by a number of factors such as restricted access to tissues, slow in vivo growth, difficulties in propagating tumour cells in vitro, limited availability of PC cell lines or immortalised cell lines for in vitro studies, lack of appropriate animal models and the complex epithelial-mescnchymal interactions. Cytogenetic studies (karyotypic analysis, FISI , CGII), loss of heterozygosity (LOH) and work on oncogenes and tumour suppressor genes are providing some insight into genetic factors contributing to the initiation, promotion and progression of $\mathrm{PC}$ in vivo.

\section{Cytogenetics}

Karyotypic analysis of many primary prostatic cancers has consistently revealed a normal male diploid karyotype (46XY) [107-109]. Cytogenetic changes can broadly be categorised as gains, losses, rearrangements and transversions. In PC, chromosomal rearrangements consisting mainly of deletions rather than translocations have been reported. Loss of chromosomes 1,2,5, 7,14, and Y or gains of chromosomes \% 14, 20,22 have been reported. Also rcarrangements of chromosome arms $2 \mathrm{p}, 7 \mathrm{q}$ and $10 \mathrm{q}$ are frequent. Aneusomy including trisomy of chromosome 7 and its association with higher tumour grade, advanced pathological stage, metastasis and early PC death have been reported by several groups utilising FISH [104, 110]. These groups suggest that genetic alterations of chromosome 7 play a significant role in the development of PC. To investigate this Takahashi and colleagues performed PCR analysis of 21 microsatellite loci on 54 paired samples. Chromosome 7 allelic imbalance was found in $30 \%$ of the cases of which $28 \%$ were losses and $2 \%$ gains. The commonest site of allelic loss was at $7 \mathrm{q} 31.1$ which correlated with increasing grade and metastasis [111].

LOH studies performed in scarch of consistent chromosomal losses can unearth putative TSGs. In 1990 Carter and colleagues examined 28 primary PCs most of which were localised stage B tumours measuring less than $2 \mathrm{~cm}$ in diameter. They found $\mathrm{LOH}$ in $61 \%$ of tumours on at least one of the chromosomes examined $(3 \mathrm{p}, 7 \mathrm{q}, 9 \mathrm{q}, 10 \mathrm{q}, 11 \mathrm{p}, 13 \mathrm{q}, 16 \mathrm{q}$, $17 p$ and $18 q$ ). Most frequently deleted regions were on $10 \mathrm{q}$ and $16 \mathrm{q}$ [112]. In approximately $20 \%$ of the tumours there was LOII of either $13 q, 17 p$ and $18 q$ or a combination [112]. These regions harbour the $R b$ (Retinoblastoma), $p 53, D C C$ (deleted in colorectal cancer) genes. Other studies have since suggested that chromosomes 8,10 , and 16 losses are 
also common in $\mathrm{PC}[113,114]$. Both Bergerheim et al. and Bova et al. found high losses of alleles on chromosome 8p $[114,115]$. Bova et al. also reported deletion of $8 \mathrm{p} 22$ in approximately $70 \%$ of their samples. These authors suggest the presence of a TSG on $8 p$ [115]. Using different techniques (PCR. ISII) and a large number of microsatellites, other groups have also reported frequent loss of markers in this region $[116,117]$. In a recent study Vocke and colleagues performed PCR based LOH studies utilising 25 microsatellite markers on the short arm of chromosome 8 on 99 microdissected PC. They found $\mathrm{LOH}$ on $8 \mathrm{p}$ in $86 \%$ of $\mathrm{PC}$ and the highest loss occurring in the $8 \mathrm{p} 12-21$ region which did not correlate with grade or stage [118]. The same group reported deletion at 8 p12-21 in $63 \%$ of PIN [119] and they suggest that deletion of this region is an early event. Their findings are at variance with those of Trapman et al. who suggested that loss of 8p12-21 correlated with advanced discase [120]. Studies of chromosome 8 suggest early proximal involvement (8p12-21) and late distal involvement (8p22) suggesting that there may be two TSGs in this region. Bova et al. reported an increased copy number of sequences on the long arm of chromosome 8 in a subset of PCs suggesting the presenec of an activated oncogene on the same chromosome [115].

To assess the effect of specific regional chromosomal losses Murakami et al. microcell transferred neomycin tagged normal human chromosome 10 into the PPC-1 (human PC) cell line [80]. This line does not contain normal copies of chromosome 10 but a complex translocation involving chromosomes 1,3 and 10 [121]. Two of their 6 hybrid clones showed decreased tumourigenicity in athymic nude mice. Structural analysis of the fragment of chromosome 10 in each hybrid suggested a putative TSC in the distal region of $10 \mathrm{p}$ [122].

In a recent report by Dong et al., a potential marker for metastatic PC was localised to chromosome 11 p12 and designated KAII [91]. KAII encodes a transmembrane protein of 267 amino acids with three potential glycosylation sites. The KAI1 protein is homologous to leukocyte adhesion molecules which function in cell-cell and cell-extracellular matrix interactions. Introduction of this gene into rat AT6.1 PC cell line suppressed their metastasis.
LOH involving $13 q$ has been reported to occur in up $1030 \%$ of primary PC. Candidate TSG on $13 \mathrm{q}$ include $R B I$ and $B R C A 2$. Cooney et al. examined LOH on $13 \mathrm{q}$ using 9 polymorphic markers spanning the entire chromosomal arm [239]. Thirty-seven of the 40 cases were also assessed for pRB, the protein product of $R b /$, by immunohistochemistry. They report a lack of correlation of $\mathrm{LOH}$ at $\mathrm{R} b \mathrm{l}$ with absent $\mathrm{pRB}$ expression suggesting the existence of another TSG in the region of $13 \mathrm{q} 14$.

Assignment of a single specific chromosome or chromosomal aberration to the development and progression of $\mathrm{PC}$ is difficult to assess at the present time and requires further investigation.

In summary, chromosomes $2,7,8,10$ and 16 appear to have a greater incidence of involvement in the development and progression of $\mathrm{PC}$.

\section{Flow cytometric analysis}

DNA flow cytometric analysis of solid tumours including PC has provided clinical information of questionable value. Most low grade PCs are diploid but may contain an extra one or two chromosomes without a distinct ancuploid pcak bcing detcetable by DNA flow cytometry [123]. Aneuploid and tetraploid tumours occur with worsening grade. It has been postulated that PCs progress from diploid to tetraploid to aneuploid to non-tetraploid aneuploid [124]. Stage A tumours were usually diploid whereas stage $\mathrm{C}$ tumours were non-tetraploid aneuploid and tumours may change ploidy with time [124].

Most investigators agree that in PC there is a correlation between DNA ploidy pattern and conventional histological grading [125]. DNA ploidy has been correlated with tumour volume and stage of disease. If a tumour has an abnormal DNA content, then the lumour volume is likely to be greater than $4 \mathrm{ce}$ [126]. However, the biological significance of ploidy in $\mathrm{PC}$ progression remains uncertain.

\section{Oncogenes: introduction and definition}

Over 100 oncogenes have been identified to date and the list is expanding. Proto-oncogenes partici- 
pate in normal growth and proliferation, encoding a wide varicty of proteins that may function as growth factors. growth factor receptors, regulators of DNA synthesis, regulators of RNA transcription, and modifiers of protein function by phosphorylation. The alteration that converts a proto-oncogene to an oncogene can take several lorms. There may be a mutation (base substitution) in the gene sequence. The prutulype of this mechanism is the ras oncogene. Single base substitutions (point mutations) at characteristic areas of the ras gene convert it into an oncogene. 'l his gene has been widely studied in a variety of tumours including urological malignancies $[127,128]$. A second mechanism occurs when there are extra copies of a normal DNA sequence gene. The prototype for this mechanism, called gene amplification include $N$-myc in neuroblastoma and $c$ erb $\mathrm{B}-2$ (also called Her-2 or $\mathrm{Neu}$ ) in breast cancer. Extra gene copy number corrclates with adverse outcomes in both these cancers. A third mechanism for conversion occurs when the oncogene is moved (or translocated) to a different place on the same chromosome or to a different chromosome. In this scenario, the normal sequence of the gene comes under control of different promoters or regulators. 'l he inappropriate or over-expression of such a gene may be oncogenic. Alternativcly, a portion of the gene sequence is translocated and this portion may fuse with a different gene sequence at a now location to create a new hybrid gene, which is an oncogene. This is called translocational rearrangement. The prototype example of translocation/rearrangement is the $c$ - $A b l$ proto-oncogene in leukaemia.

Research regarding oncogenes in PC has been limited and to date no oncogene has been correlated with initiation or progression of $\mathrm{PC}$ [129]. Those that have been studicd in PC include ras, myc and c-erb-B-2. Members of the ras gene family, c.g., Harvey $(\mathrm{H})$-, Kirsten (K)-, and Neuroblastoma (N)-ras have been most widely studied in PC.

\section{Mutations in ras genes}

$\mathrm{C}$-H-ras, $c$-Ki-ras and $c$ - $N$-ras proto-oncogenes comprise the ras family of genes. These closely related genes encode a $21 \mathrm{KD}$ protein (p21). C-Ras genes are activated after a single base mutation or with deregulated expression of the wild type alleles.
Ras p21 protcins accumulate in their GTP-bound state and initiate a cascade of events that lead to DNA synthesis through well characterised pathways in response to a mitogenic stimulus [130].

Mutations in ras genes have been reported frequently in human tumours $[127,128]$. Molecular analysis in primary and metastatic PC has demonstrated that none are commonly mutated in PC [131-137]. LNCaP cells transfected with non-mutated $c$-ras expressed high levels of p21 protein. High levels of p21 expression in $\mathrm{LNCaP}$ cells did not afrect their growth properties. However, LNCaP cells transfected with a mutated $v$ - $K$-ras became androgen independent and showed increased anchorageindependent colony formation [138]. Transfection of a mutated $v$-H-ras into a non-metastatic Dunning rat prostatic cell line resulted in acquisition of metastatic phenotype [139-141].

The frequency of $H$-ras point mutations in patients in the IJSA is estimated to be less than $5 \%$ $[131,134,135,142]$. In contrast Konishi et al. found $K$-ras 12 mutations in approximately $25 \%$ of latent autopsy prostatic tumours in Japanese males [135]. The incidence of clinically manifest PC in Japanese men is approximately 5 fold less than that observed in the North American population. There may be a difference between latent and clinically evident cancers or there may be racial differences [135]. Anwar et al. reported a $24 \%$ mutation rate in clinical PCs from Japanese men. Approximately $70 \%$ of the mutations detected were restricted to codon 61 of I-ras. They also reported the detection of human papilloma virus (HPV) DNA in greater than $40 \%$ of PCs analysed [136]. The cumulative data on ras mutations suggests that the overall incidence in clinically manifest $\mathrm{PC}$ is less than $5 \%$ and that this is not a common event in either initiation or progression. Most of the mutations found in non progressive latent disease were those associated with $K$-ras (A to $T$ transversion in codon 61) whereas clinically manifest ones are associated with $H$-ras.

Expression of $p 21$ protein and $m R N A$. Several groups claimed enhanced ras $\mathrm{p} 21$ expression in primary prostatic carcinomas which correlated with increased Glcason grade $[143,144]$. Antibodies utilised in these studies were later found to be non-spe- 
cific and further studics have failed to show an association between $\mathrm{p} 21$ expression and tumour stage or grade [145]. Expression of p21 has also been assessed in primary and metastatic tumours from the same patient by Fan who found that most of the metastatic tumours expressed $\mathrm{p} 21$ whereas only a fifth of the primaries did. He postulated that the metastasis originated from the primary ras expressing tumour cells. Increases in $c-H-r a s$ m-RNA expression have been demonstrated in tumours which evolve from low grade androgen-dependent into high grade androgen-independent tumours [146, 147]. Expression of both $K$-ras and $N$-ras have been evaluated and there is no reported association between expression and tumour grade.

Myc genes in PC. Myc proteins are members of the helix-loop-helix-leucine zipper (HLH-Zip) family of transcription factors, which either homo- or hetero-dimerise with other members of the family. In most cases, dimerisation permits subsequent DNA binding, a function mediated by a highly basic region adjacent to the HLH-ZIP dimerisation motif. Myc proteins also contain distinct transcriptional activation domains that modulate the expression of genes to which the protein bind [148].

Genes regulated by $c-m y c$ are not known. Abnormalitics (amplifications, chromosomal translocations or otler genclic events) of $c$-myc have been detected in various types of human tumours. $c$-myc is amplified or rearranged in approximately $30 \%$ of breast tumours [149] and in differing rates in ovarian, colon, uterine and stomach tumours. There are conflicting reports in the literature regarding c-myc expression in prostatic carcinomas. Several studies have shown an increased c-myc m-RNA expression in PCs compared to benign prostatic hyperplasias and normal tissues and an association with tumour grade [150154]. Other studies have failed to show such an association $[155,156]$. The $c-m y c$ gene does not appear to be amplified in PC $[132,152]$. These discrepancies are most likely to be due to the different methodologies employed. Collectively these studies would suggest that c-myc overexpression is not fundamental in $\mathrm{PC}$.

In a mouse prostate model, $v I I$-ras alone at high levels was found to induce dysplasia, while $c-m y c$ over-expression induced hyperplastic lesions [157].
Double c-myc/ras transgenics induced transtormation and $\mathrm{PC}$ [158].

C-erbB-2 in $P C$

$c$-erbB-2 is on chromosome $17 \mathrm{q} 21-\mathrm{q} 22$ and encodes a transmembrane phosphoprotein which has considerable sequence homology to the epidermal growth factor (EGF) receptor. The most common mechanism of $c$-erbB-2 activation is by gene amplification with a resultant over-expression of both the transcriptional and translational products. In addition to amplification, $c-e r b B-2$ activation in several tumours has been shown to occur by over expression of mRNA and protein without DNA amplification or just by protein over-expression [159]. This oncogene has been most widely studied in breast carcinomas in which amplification/over-expression has been correlated with poor prognosis [160-162]. c-erbB-2 expression studies in PC have yielded conflicting results [163-170]. Overall it appears that a subset of prostatic adenocarcinomas express immuno-detectable $c$-erb $B$ - 2 protein. The antibodies employed in the various studies (monoclonal and polyclonal), the detection methods, and whether the samples were fixed or frozen could all have contributed to the conflieting results.

\section{Other oncogenes}

The $c$-sis proto-oncogene has also been studied in PC. Its product is identical to the $\beta$ chain of platelet derived growth factor (PDGF). C-sis may play a role in the growth of prostatic tissue by androgens and its suppression by corticosteroids [151,171]. Dot blot RNA analysis showed an increase in c-sis cxpression in poorly differentiated prostatic adenocarcinomas [151].

$c$-fos oncogene encodes a protein FOS which forms heterodimers with JUN proteins that function as positive or negative transcription factors binding to specific DNA sequences via basic domains adjacent to the dimerizing helices. There has been little work in PC but some evidence that there may be a relationship betwcen androgen receptor content and c-fos expression [151, 172, 173]. Androgen deprivation has been shown to reduce c-fos expression by $90 \%$ in some cell lines [172]. No gene amplification has been seen in PC (26). 
$B C l-2$ is a cell death 'suppressor' gene on chromosome $18 \mathrm{q} 21$ whose protein is normally undetectable in a majority of hormone dependent PCs. Hormone refractory PCs in contrast express high levels of bcl-2 protein [174]. Expression of bcl-2 protcin in PCs appears to be associated with the transition to hormone (androgen) independence [175].

The steps involved in cellular transformation and the development of the metastatic phenotype are poorly characterised in $\mathrm{PC}$. The formation and dissemination of a tumour could be due to an accumulation of specific, consccutive genetic alterations with time as in the case of colorectal cancer [176]. Results published by Carter et al. favour a multistep process, and this would explain the increasing frequency of PC with age [158]. Genes involved in this process are those involved in cell cyle control, apoptosis, proliferation, differentiation (oncogenes and tumour suppressor genes) and those involved in DNA repair, proteolysis, cell adhesion and motility.

\section{Tumour suppressor genes}

Inactivation of tumour suppressor genes (TSG) results in loss of function. Usually both alleles of TSGs are lost, inactivated or damaged, resulting in either loss or attenuation of the gene product which was necessary in suppressing the neoplastic phenotype. Two well known TSGs, the retinoblastoma (RBI) $[177,178]$ and the $p 53$ genes $[179,181,182]$, have been implicated in a number of neoplasms $[183,184]$. Other recently identified TSGs are Wilm's tumour gene ( $W T I)$, DCC (deleted in colorectal cancer), $A P C$ gene (adenomatosis polyposis coli gene) type 1 neurofibromatosis gene ( $N F 7$, $M E N$ (multiple cndocrine ncoplasia gene) and the $B R C A 1$ and 2 (breast cancer) genes [178, 179].

\section{Retinoblastoma gene (RB1)}

This was the first identified TSG. It is located on chromosome $13 \mathrm{q} 14.2$ and its message size is approximately $4.7 \mathrm{~Kb}$ coding for a $105 \mathrm{kDa}$ nuclear phosphoprotein termed p105 ${ }^{\mathrm{kb} 1}$. It binds to double stranded DNA in a non-sequence specific manner and acts through a motif (the retinoblastoma control element, RCE). p105 ${ }^{\mathrm{Rbl}}$ interacts with a large num- ber of proteins many of which are transcription factors including cell cycle related proteins in particular the E2F family of transcriptional factors. E2Fp $105^{\mathrm{kbl}}$ association prevents transcriptional activation of a varicty of genes, the products of which are central to the onset of DNA synthesis in the $S$ phase of the cell cycle. Cell division is therefore prevented as cells are checked in the G1 phase. Mutations of the $R B I$ gene have been described in a variety of hu man tumours in including osteosarcomas, soft tissuc, bladder, breast, and lung tumours [185-190]. In 1990 Bookstein and colleagues infected the DU 145 human PC cell line (which produces a truncated isoform of $\mathrm{Rb}$ protcin) with a recombinant retrovirus containing a normal $R B 1 \mathrm{cDNA}$. Infected DU 145 cells expressing the normal $R B 1$ were non-tumourigenic when injected into nude mice compared to the parental cells. The authors concluded that $R B I$ inactivation could play a role in the development of $\mathrm{PC}$ $[191,192]$. Brooks et al. reported loss of a single $R B I$ allele in $27 \%$ of PCs suggesting that inactivation of this gene may play a role in the development and progression of PC in a subset of tumours [193].

p53

The $p 53$ gene has been mapped to the short anil of chromosome 17 at $17 \mathrm{q} 13.1$. It encodes a $53 \mathrm{kDa}$ nuclear phosphoprotein that is postulated to arrest cells in $\mathrm{G}_{1}$ (for revicws see $[194,195]$ ). For cellular growth to occur, cells must enter the S-phase and p53 cell growth arrest must be inactivated. Loss of the normal function of p53 has been implicated in many different human tumours including urological tumours $[182,196-198]$. Wild-type p53 protein is a sequence specific transcription factor which can activate genes possessing the $p 53$ consensus sites. Over expression of wild type $p 53$ can cause repression of many genes. p53 has been implicated as a key mediator of the cellular response to DNA damage. DNA damage induces accumulation of active wild-type $\mu 53$ which can arrest cells in G1 or induce apoptosis.

Analysis of p53 broadly falls into two categories: (a) Immunohistochemical and western blot analysis of accumulated p53 protein, (b) molecular analysis e.g. PCR followed by SSCP and direct sequencing. The frequency of $p 53$ mutations in primary PCs is low (10-20\%) compared to the observed frequency 
of mutations in other human tumours [199-202]. Several groups have found a higher frequency of p53 mutations in PC bone metastasis [203-205]. Navone and colleagues found a higher rate of p53 accumulation in association with higher Gleason grade $(30 \%$ of Glcason score $8-10$ compared with none of the lower score tumours) and androgen independent tumours [203]. In summary, mutated p53 is found in less than $20 \%$ of PCs and is associated with increased rate of cellular proliferation, grade, stage and androgen independence. These studies suggest that p53 mutations are a late event in the development of $\mathrm{PC}$.

\section{Androgen receptor in $P C$}

The human androgen receptor (AR) is a member of the ligand activated steroid thyroid hormone transcription factors [206]. The gene (>90 Kb) is located on the X chromosome (Xq11-12) [207] of which the coding region is separated over cight exons [208]. Two AR mRNAs ( $11 \mathrm{~Kb}$ and $8.5 \mathrm{~Kb}$ ) have been demonstrated in prostatic tissue which are generated by alternative splicing in the 3 ' untranslated region [208]. The AR cDNA sequence possesses an open reading frame of 2730 bp encoding a protein of 910 amino acids with a molecular mass of $98.5 \mathrm{kDa}$. There are four functional domains: (a) a highly polymorphic, $\sim 550$ amino acid N-terminal portion which modulates the amplitude [209, 210] and probably the specificity of its target gene effects; (b) a central 67 amino acid DNA binding domain (DBD); (c) an 8 amino acid nuclear localisation signal [209, 210]; and (d) a C-terminal $250 \mathrm{ami-}$ no acid hormone binding domain (HBD).

The $\mathrm{N}$ terminal domain is characterised by a high abundance of acidic residues and by the presence of several homopolymeric residues of which expansion of one of the polyglutamine strctches results in decreased transaction. The AR's DBD has a 'Dbox' on its C-terminal zinc finger for normal dimerisation [211]. Once bound, the AR's HBD has transcriptional regulatory properties and contributes to dimerisation and nuclear localisation [210, 212]. Phe-581 and Arg-614 are strictly conserved residues of the DBD with Phe- 581 being a key component of the discriminatory N-terminal-helix of the DBD which is associated with the affinity and specificity of AR-androgen response element (ARE) binding.

Androgens are required for the development of both the normal prostate and PC. Although an initial subjective response to hormonal therapy is observed in $70-80 \%$ of patients with advanced disease, most tumours progress within 2 yrs to an androgen independent state. The proposed nileclianism of progression to androgen independent growth includes the loss of AR expression [213], amplification of the AR gene [214] and structural changes in the AR protein [215].

Biochemical determination of AR levels have demonstrated their presence in both cytosol and nuclear fractions of benign and malignant prostatic cclls $[216,217]$. Nuclear AR (ARn) has been shown to be four fold less in metastases than in primary cancer [218]. Masai et al. demonstrated immunodetectable AR localisation in the nuclei of both benign and malignant cells [219]. In cancer tissuc ( $n=$ 63 untreated) AR positive and AR negative cells were intermingled and the percent of strongly positive cclls inversely correlated with Gleason grade [219]. In relapsed PC $(n=8)$ there was a significant decrease in AR positive cells compared to the untreated PC of a similar grade [219].

There are numerous reports of mutations associated with the coding region of $\mathrm{AR}$ but there appear to be conflicting data on the frequency of these mutations. Initial data suggested that in primary $\mathrm{PC}$, mutation frequency was low $[220,221]$ and in a recent study Ruizeveld de Winter et al. found no mutations in exon 2-8 or major changes in exon 1 in 18 hormone refractory carcinomas [33]. However, Tilley et al. have presented data in which mutations occurred in $44 \%$ of the primary tumours ( $25 \mathrm{pa}-$ tients) analysed. These latter findings support the hypothesis that the rapid onset of androgen insensitive progression of PC may be due to selective outgrowth of cells with existing mutated AR rather than the acquisition of new mutations with the onset of treatment. A high proportion of mutations have been demonstrated in the ligand binding domain of the AR in hormone refractory $\mathrm{PC}[222]$ and in metastatic PC.

Ovcrexpression of amplified genes is associated 
with acquired resistance to cancer treatment. Visakorpi et al. demonstrated AR gene amplification in $30 \%$ of hormone refractory tumours or those analysed before androgen deprivation therapy [214]. The clevated copy number (up to 4 fold) is associated with enhanced AR transcription which may facilitate tumour cell growth in the presence of low serum androgen levels remaining after conventional endocrine treatment.

The transcription activation domain of the AR resides in the $\mathrm{N}$-terminal region (encoded by exon I) which contains the polymorphic trinuclcotide repeats $\mathrm{CAG}$ [223] and GGC [224] coding for polyglutamine and polyglycine respectively. The average length of the CAG microsatellite in the population is $21 \pm 2$ (range 11-31 CAGs) [223]. Elimination of the polyglutamine tract resulted in clevated transcription activation (TA) and progressive increase of the CAG caused a linear decrease of TA [225]. It may be that shorter CAG alleles result in more active cell growth, due to greater AR transactivation activity, even at low levels of androgens during endocrine therapy. Irvine et al. demonstrated that short CAG alleles (<22 repeal) were highest $(75 \%$ ) in African American males who also have the highest risk of PC and lowest (49\%) in $\Lambda$ sians who are at a low risk of PC [226]. In the 47 patients with $<22$ CAG repeats $43 \%$ possessed long GGC alleles (>16 repeats) [226]. Ruizcveld de Winter el al. found no expansion or deletions in the $\mathrm{CAG}$ repeat isolated from 18 hormone refractory and 9 normal prostate samples and in a study of an additional 40 PC specimens only one somatic CAG contraction ( $24 \rightarrow 18$ CAG's) was observed [227]. These data would suggest that somatic expansion or contraction of the CAG repeat is a rare event in the pathogenesis of $\mathrm{PC}$.

\section{Growth factors}

In spite of maximal androgen deprivation therapy, many PCs become androgen independent, and autocrine and paracrine peptide growth factors assume greater importance [228].
The TGF-beta superfamily may be divided into subfamilies according to sequence homology. One group consists of TGF-beta 1, 2 and 3 . The biologically active form of TGF-beta is a $25 \mathrm{kDa}$ disulphide linked homodimer of mature segments although heterodimers have also been found. TGFheta has been implicated in various biological processes affecting growth and differentiation with roles in angiogenesis, immunosuppression, as well as inhibition of cellular proliferation [229].

The mechanism of TGF-beta $a_{1}$ action on prostatic cell growth is unclear. TGF-beta ${ }_{1}$ binds the TGFbeta receptor II (TbetaR-II) which reciuits the TGF-beta receptor I (TbetaR-I) inducing a signal transduction cascade. 'TGF-beta ${ }_{1}$ prevents phosphorylation of the retinoblastoma gene product (RB) which would normally increase c-myc expression and accelerate proliferation. This would suggest that TGF-beta ${ }_{1}$ should inhibit proliferation. Thus, one mechanism for escaping TGF-beta ${ }_{1}$ control would be to down-regulate TbetaR-I or TbetaR-II. Proliferation in PC-3 and DU-145 but not LNCaP cell lines is inhibited by TGF-beta. LNCaP $_{1}$ cells are insensitive because the gene for TbetaR-I is defective [230]. There is a variable response to TGF-beta ${ }_{1}$ in the DU-145 cell lines, possibly due to a mutated RB product arising from clonal variation [231, 232].

Higher levels of immunoreactive TGF-beta have been reported in patients wilh $\mathrm{PC}$ compared to BPH. Increased expression of immunodetectable TGF-beta ${ }_{1}$ was found in malignant epithelial cells compared to BPH samples [233]. Recent data suggest that elevated levels of plasma TGF-beta dis- $^{-}$ criminatc between patients with invasive and noninvasive discase [234].

Reconciling the cvidence from clinical data, in $v i$ vo and in vitro experiments is difficult. This may be because TGF-beta exhibits differing actions on the same cells at different concentrations. However, studies with Dunning rat MAT LyLu cells in vitro indicate that the effect of TGF-beta ${ }_{1}$ depends also

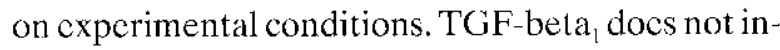
hibit MA'I' LyLu proliferation when cells are grown at high density, in the presence of serum, bFGF or 
EGF (partial response only), or when grown on matrigel rather than plastic [235]. MAT LyLu cells transfected with TGF-beta, produce more and larger metastases in vivo than controls [236]. Growth in vitro can be inhibited in cells expressing

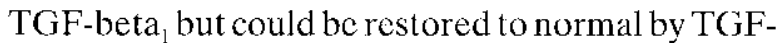
beta inhibiting antibodies. Evidence from human cell lines confirms the variable effect of TGF-beta ${ }_{1}$. Growth in PC-3 and DU-145 cell lines is inhibited

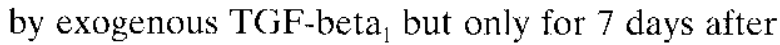
which the effect is lost [237]. PC-3 and DU-145 cells secrete TGF beta into the media in vitro allowing either for autocrine control of growth or potentially paracrine eflects on stromal cells.

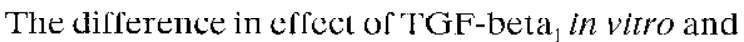
in vivo probably relates to the effect TGF-beta ${ }_{1}$ has on other factors affecting tumourigenicity including relcase activation of matrix metalloproteinases (MMPs) [238] reduced host immune response and angiogenesis. TGF-beta also has powerful effects on fibroblasts inducing growth, collagen synthesis and MMP secretion, which then modifies the extracellular environment which in turn affects tumour ccll behaviour.

\section{TGF-alpha, epidermal growth factor $(E G F)$ and epidermal growth factor receptor (EGFR)}

EGF and TGF-alpha show sequence homology and both act through EGF membrane receptors $\left(\mathrm{E}\left(\mathrm{i} \mathrm{H}^{\mathrm{K}}\right)\right.$. $\mathrm{E}(\mathrm{jHK}$ is a receptor for several other ligands including heparin-binding EGF like factor, amphiregulin and vaccinia virus growth factor. Binding of EGF to its receptor increases receptorreceptor affinity, dimerisation of the cytoplasmic tyrosine kinase domain of EGFR and trans-phosphorylation. The receptor-ligand complex undergoes receptor mediated endocytosis. In some primary tumours EGFR is amplified by up to 50 fold including about $20 \%$ of bladder tumours. In $\sim 20 \%$ of primary breast cancers EGFR is amplificd and strongly associated with early recurrence and death in lymph node positive patients. The EGFR gene is located on chromosome 7p13-12 and trisomy 7 has been reported in a significant number of PCs [110].

Increased immunodetectable TGF-alpha expres- sion has been reported in samples of PC compared to benign prostatic tissue [240]. Ching et al. reported significantly increased mRNA expression of both pre-pro TGF alpha and pre-pro-EGF in $\mathrm{PC}$ compared to $\mathrm{BPH}$ and levels of EGF $\mathrm{mRNA}$ are higher in PC than BPH [241]. Increased EGFR mRNA has also been reported in PC where expression was found to correlate with grade [242]. However, classifying patients by FGFR status does not distinguish survival in patients with early versus late stage disease [243].

EGF stimulates proliferation of both DU-145 and LNCaP cells plated at low density [244, 245] and TGF-alpha has a similar effect on PC-3 cells [246]. Expression of EGFR can be modulated by exogenous androgens in LNCaP and ALVA 101 cell lines [247-249]. When the normally androgen-insensitive PC-3 cell was transfected with the human androgen receptor, levels of EGFR were increased and the proliferative response to exogenous EGF and dihydrotestosterone increased synergistically [250]. The role of the androgen response element in the transcriptional regulation of FGFR is unknown.

Transfection studies with a truncated EGFR into DU 145 cells have suggested a role for the TGF-alpha/EGF autocrine loop in invasion in vitro [251]. Stimulation of PC-3 cells with EGF increases urokinlase-Plasminogen Aclivalor (u-PA) levels on northern blot analysis and enhances their invasiveness in vitro [252,253]. Similarly, EGF increases the migration of the TSUPr1 PC cell line through Boyden chambers.

Therapeutic strategies have been suggested based on EGF control of PC. EGFR expression is reduced in Dunning rat AT-1 cells and survival in vivo is prolonged after somatostatin [254] and $\mathrm{LH}$ RH analogue therapy [255]. Suramin reduces binding of TGF-alpha to TGF-alpha receptors, inhibits growth and increases the fraction of PC 3 and DU-145 in the $S$ phase [256]. Such therapies may eventually prove of use in clinical practice.

\section{$l G F$}

The insulin-like growth factor (IGF) axis is a multicomponent network of molecules involved in the regulation of cell growth. It includes two major li- 
gands, (IGF-1 and IGF-2), ccll surface receptors, (the type 1 IGF receptor family as well as the type 2 IGF receptor), a family of high affinity binding proteins which regulate $I G F$ availability to the receptors (the IGFBPs) and a group of IGFBP proteases which clcave IGFBPs and modulate IGF action.

IGF-1 is a 70 amino acid polypeptide which is functionally similar to insulin [275]. Progression through $\mathrm{G}_{1}$ to the $S$ phase in the cell cycle is accelerated by IGF. IGF-1 and IGF-2 are similar and are usually bound to $\mathrm{IGF}$-binding proteins.

PC -3 cells have been shown to produce IGF like factors [258]. IGF-1 induces proliferation of the DU-145 and PC-3 cell line, but LNCaP cell lines have fewer IGF-1 receptors and do so only in the presence of androgen [259]. There was no evidence in the latter study that the cell lines produced IGF themselves, but in another study using radioimmunoassay substantial quantities of IGF-1 were observed [260]. Another rat PC cell line cxhibited increased growth when exposed to IGF and expressed predominantly IGF-1 receptors [261]. IGF-1 may act directly through the androgen receptor pathway [262].

\section{$F G F$}

There are at least 9 members of this family which bear 30-35\% sequence homology with each other. Basic FGF (FGF-2) and to a lesser extent acidic FGF (FGF-1) are found in both benign and malignant prostates. FGF mediates its effect by tyrosine kinases and induces proliferation mediated by $\mathrm{p} 21$ ras. Keratinocyte growth factor (FGF-7) is produced by stromal cells and acts in a paracrine fashion on prostatic epithelial cells. As PC develops, the sensitivity of the $\mathrm{FGF}$ receptors for $\mathrm{FGF}-2$ increas- cs. FGF-2, FGF-5, and FGF-3 levels have been noted to be elevated in PC. Work from cell lines indicates a slightly different relationship. Human PC cell lines (DU-145, PC-3, LNCaP) do not appear sensitive to FGF-2 when added to culture medium $[264,265]$ although it can be found within the cclls. More recently attention has focused on FGF8, also known as androgen inducible growth factor. This is expressed in prostatic epithelial cells and appears to correlate with AR expression (our unpublished observations).

\section{Other growth factors}

\section{Endothelins}

Endothelins (ET) are 24 amino acid polypeptides that are abnormally elevated in the plasma of men with metastatic PC [266]. Threc endothelins (ET-1, ET-2, ET-3) have been identified of which ET-1 protein is detccted in primary and metastatic sites of human PC [267]. There are two receptors for endothelins $\mathrm{ET}_{\mathrm{A}}$ and $\mathrm{ET}_{\mathrm{p}}$. In $\mathrm{BPH}, \mathrm{ET}_{\mathrm{D}}$ receptors are found on prostate epithelial cells but in cancer $E T_{\Lambda}$ receptors predominate $[267,268]$. Loss of $\mathrm{ET}_{\mathrm{B}}$ receptors may be of advantage because these mediate the production of nitric oxide (NO) $[269,270]$. The role of NO in tumour biology is unclear, but it has been shown in other systems tu induce apoptosis, be cytotoxic in vitro, inhibit metastases but paradoxically promole tumour growth in vivo [271,272]. Exogenous ET-1 induces P' proliferation which can be prevented by sclective block of $\mathrm{ET}_{\mathrm{A}}$ receptors [267]. ET-1 also augments the proliferative response to IGF-1, IGF-2, PDGF, bFGF, and EGF in serum-free conditions. NO inhibits the release of ET-1 from endothelium and receptor binding of ET-1 to its receptors $[273,274]$. The role of ET-1 and

Table 5. Integrins found in PC-3 cells

\begin{tabular}{|c|c|c|}
\hline Integrin & ECM component & Ref \\
\hline$\alpha 2 \beta 1$ & collagen type I; laminin & {$[294,400]$} \\
\hline$\alpha 3 \beta 1$ & entactin; laminin: decreased in invasive $P C-3$ sublines & {$[294,297,401]$} \\
\hline$\alpha 6 \beta 1$ & laminin: cxpressed less in invasive $\mathrm{PC}-3$ subline & {$[294,401,402]$} \\
\hline$\alpha 6 \beta 4$ & laminin; increased in invasive $\mathrm{PC}-3$ subline & {$[288,294]$} \\
\hline$\alpha \vee \beta 3$ & vitronectin: fibronectin; ostcopontin & {$[294,400]$} \\
\hline
\end{tabular}


its activity through $\mathrm{EI}_{\wedge}$ receptors and the loss of $\mathrm{ET}_{\mathrm{B}}$ reccptors in the actiology of $\mathrm{PC}$ remains to be fully established.

\section{Nerve growth factor (NGF)}

NGF is found in the prostatic stroma and NGF receptors are found in prostatic epithelial cells in $\mathrm{BPH}$, cancer and normal tissue [275]. It is found in the conditioned media of TSU Pr1, PA-III PC cells and human prostatic stromal cell lines and is important in paracrine interaction between stromal and cpithelial cells in vitro [276,277]. Cellular migration through Boyden chambers is enhanced by protein derived from stromal cells and reduced by addition of NGF antibodics [278]. Prostatic tumour cells growing near nerves show a lower apoptotic index than cells away from nerves and this may be due to NGF which is known to have proliferative effects on non-neuronal cells $[279,280]$.

\section{Other growth factors}

Spermine is an endogenous polyamine present in aqueous extracts from the prostate. It is growth inhibitory to PC-3 cells in vitro and AT-3.1 cells in vivo [281]. Levels of erythrocytc spermine may discriminate between patients with androgen sensitive and insensitive tumours and those likely to relapse following initial treatment [282]. Prolactin, which is probably necessary for citrate production by the prostate [283], appears to alter proliferation of the PC-3 cell line dose-dependently and increase it in the LNCaP ccll line [284]. Early work suggests patients with $\mathrm{PC}$ treated by androgen deprivation showed lower serum prolactin levels with an improved response to treatment when bromocriptine was added [285].

\section{Cell adhesion molecules (CAM)}

A single cell uses multiple mechanisms to adhere to other cells and the extraccllular matrix (ECM). CAM expression is relevant to understanding the genesis of the invasive and malignant phenotype, and also in defining prognostic categories and in the development of new thcrapeutic strategies.

\section{Integrims}

Integrins are a family of heterodimeric cell surface glycoproteins which connect the basolateral surface of the cell to the extracellular matrix (c.g. basement membranc) or partake in intercellular adhesion [286]. Multiple hetcrodimers of over 16 alpha and 8 beta subunits may be formed and are dependent on divalent cations $\left(\mathrm{Ca}^{++}\right.$or $\left.\mathrm{Mg}^{++}\right)$. Patterns of integrin binding are complex. Some bind identical ECM components but transduce different signals from outside to inside the cell [287].

Normal human prostatic basal cells express alpha: $2,3,4,5,6$, v and beta: $1,4,7$ subunits [288-290]. In PIN, the hemidesmosomal proteins alpha6 bcta4, alpha3 beta1, alpha6 beta1 integrins are preserved whercas in $\mathrm{PC}$, alpha2, alpha4, alpha5, alphav and beta4, alpha6 beta 4 integrins tend to be redistributed or lost [288-292]. In the DU-145 cell line, preservation of alpha 6 integrins increases invasiveness in vivo and motility on laminin in vitro [293]. Although some investigators have found rcduced alpha3 levels in an invasive $\mathrm{PC}-3$ subline [294], invasive carcinoma in patients is associated with preservation of alpha3 beta1 and alpha6 betal integrins which become expressed diffusely instead of basolaterally. This integrin may allow binding to the basal lamina in blood vessels, nerve and muscle [288-292]. A novel alpha3 subunit with the beta1 subunit has been identified that binds transferrin, which is implicated in $\mathrm{PC}$ cell proliferation in bone [295, 296]. Cytokine treatment of PC-3 and DU-145 cells reduces alpha3 expression and this suggests strategies for treatment [297].

A variety of integrins arc expressed by PC-3 cell lines (Table 5). LNCaP cclls express decreased levels of alpha 3 compared to PC-3 or DU- 145 cells and this has been suggested as one reason why this cell line is less invasive than the other two $[297,298]$. When an invasive PC-3 subclone was generated, alpha3 betal integrins were expressed less than normal [294]. Interestingly, LNCaP cclls grown on plastic express considerably less alpha3 than PC- 3 cells which can be down-regulated by a variety of cytokines [297]. These results are difficult to reconcile, however these studies suggest ways that integrins may be important in the invasive process. 


\section{Cadherin}

The cadherins are responsible for $\mathrm{Ca}^{+\tau}$-dependent adhesion. There are over 25 types of cadherins, each encoded by a separate genc, and named after the tissue in which they were first found. Cadherins are confined to epithelia and are a master molecule of differentiation inducing compaction in the blastomer, cellular polarity, and cell-cell adhesion. Cadherins act by a homophilic homotypic mechanism and play a pivotal role in cell-cell adhesion.

Most cadherins are $120 \mathrm{kDa}$ single-pass transmembrane glycoproteins composed of 700 to 750 amino acid residues. The extra-cellular part consists of 5 domains, four of which are homologous and contain $\mathrm{Ca}^{2+}$ binding sitcs. Without $\mathrm{Ca}^{2 \div}$, the extraccllular domains collapse and the cells separate frum each other.

E-cadherin is the best known of the cadherins and is concentrated in the adhesion belts of mature polarised cpithelial cells between their apices and gap junctions. It is connected through the $\mathrm{COOH}$ terminal tail of E-cadherin to the cortical actin cytoskclcton via alpha-, beta-, and gamma-catenin, vinculin, alpha-actinin and plakoglobin. Gamma catenin is identical to plakogobin and alpha catcnin shares homology at the protein level with vinculin which is located at the adherens junctions and focal contacts. This forms a transcellular network of proteins which can contract in the presence of myosin motor proteins.

Most cells express a combination of cadherins: basal cells in the prostate cxpress both $\mathrm{P}$ - and $\mathrm{E}$ cadherin whercas luminal cells cxpress E-cadherin only [299]. 'l'hey are of considerable interest because a significant proportion of prostatic tumours exhibit loss of heterozygosity at $16 \mathrm{q}$, the region to which E-cadherin has been mapped (16q22), suggesting a putative invasive suppressor gene [300].

Several studies have shown strong relationships between the grade and stage of PC and E-cadherin [301]. Studics examining E-cadherin expression in formalin fixed paraffin embedded prostatectomy specimens show decreasing E-cadherin expression associated with increasing Gleason score with an accompanying decreasc in E-cadherin expression in lymph node metastases compared to primary tis- suc [302-304]. Immunohistochcmical expression patterns have also been associated significantly with survival after radical prostatectomy [305]. Whether E-cadherin expression is an independent predictor of survival when incorporated with models of Gleason score, PSA and stage has yet to be conclusively demonstrated.

In the Dunning model, there is an inverse relationship between E-cadherin expression and invasive phenotype $[306,307]$. Following a single passage of the $\mathrm{H}$ cell linc, a very aggressive anaplastic cell line was derived. This was metastatic immediately following administration and was named AT-6. It was shown that decreased E-cadherin expression occurred concomitantly with the acquisition of metastatic ability.

Abcrrant hypermethylation of $5^{\prime} \mathrm{CpG}$ islands within the proximal promoter region of $\mathrm{E}$-cadherin has been shown in the PC cell lines TSUPr1 and DUPro [308] and may be one of the mechanisms lcading to loss of functional E-cadhcrin expression. Demethylation can lead to re-expression of E-cadherin [309]. Functional E-cadherin can also be inaclivated by phosphorylation of the associated catenins or aberrations in these protcins.

PC- 3 cells express E-cadherin mRNA but are deficient in alpha-catenin because of a large homozygous deletion of the gene. Reintroduction of normal alpha-catcnin DNA or microcell-mediated transfer of chromosome 5 restores E-cadherin function and the presence of tight junctions leading to the suppression of PC-3 growth in vitro and tumourigenicity in vivo [310, 311]. A relationship between the potential TSG product APC and beta-catenin exists in that the APC competes for binding with beta-catenin [312]. Binding of catenins to FGF receptor or to cadherin results in phosphorylation events. There is evidence from the LNCaP cell line that E-cadherin is regulated by androgens [313], which may be relevant in the sequence of events underlying the development of androgen independence and tumour progression.

\section{$C \cdot C A M$}

Cell-CAM (C-CAM) is a member of the immuno- 
globulin superfamily of proteins with scquences similar to the carcinocmbryonic antigen (CEA) and whose human homologue is CD66a [314]. C-CAM binds by homophilic interactions with other cell adhesion molecules and is $\mathrm{Ca}^{\prime \prime}$-independent. C-CAM expression can be regulated by androgens [315] and is predominantly expressed continuously on the cell membrane of normal human tissue but becomes discontinuous in BPH and PIN and completely $\mathrm{ab}-$ sent in PC [316]. The cytoplasmic domain of CCAM 1, which is an isoform of C-CAM, contains several potential phosphorylation sites for CAMPdependent kinase and for tyrosine kinase, but these are probably important in signal transduction rather than cell adhesion [317]. Single dose transfection of an isoform of C-CAM1 into PC-3 cells by an adenovirus results in stable expression of C-CAM1 and suppresses growth in vitro and lumourigenicity in nude mice $[318,319]$.

\section{Intercellular-cell adhesion molecule-1 (ICAM-I)}

ICAM-1 is an early marker of immune activation and response and it is the counter-receptor for I.FA-1 (lymphocyte function-associated antigen) on T-cells. It is important in the conjugate formation between tumour infiltrating lymphocytes (TILs) and their target inducing both tumour cell death and natural killer ccll-mediated cytolysis. Theoretically, up-regulation of ICAM-1 should enhance the host immune response against the tumour, but dissemination of tumour cells is enhanced because of tumour cell attachment to circulating lymphocytes. ICAM-1 levels are inducible by cytokines (IL-2, interfcron-gamma, interferon-alpha, TNF-alpha) in PC-3 and DU-145 cells in vitro; LNCaP cells barely express ICAM-1 and it is not inducible by cytokine treatment [297]. It has yet to be shown that cytokine treatment reduces invasion and metastatic spread as a result of ICAM-1 expression. Circulating ICAM-1 levels are similar in controls, pationts with $\mathrm{PC}$ and $\mathrm{BPH}$, and are not useful as a staging tool [320].

\section{Angiogenesis}

Folkman and co-workers have provided new insights into possible mechanisms regarding tumour ncovascularisation and how it alfects clinical presentation [321]. Prostatic tumours are not usually angiogenic at the time of first development and avascular tumours stop growing after reaching 1-2 mm in diameter. Eventually some new capillaries are recruited from pre-existing blood vessels. The tumour grows not only because of the increased perfusion, hut also because of the release of growth factors and extra-cellular matrix proteins from endothclial cells [322].

Angiogenesis is promoted by products released from tumour cells, infiltrating tumour-associated macrophages and the endothelium itself. Angiogenesis is of importance at two critical stages during the development of metastases: the time of shedding into the circulation and establishment at a new site [323]. Multiple factors can induce or inhibit an angiogenic response. Many of these factors may be produced or acted upon by the endothelial cells or prostatic tumour cells themselves.

In other tumour systems, the primary tumour releases both stimulatory and inhibitory agents which have markedly different half-lives in the circulation. The balance of these determines in part the clinical scenario [321]. Vascular Endothelial Growth Factor (VEGF) is produced in the human normal prostate [325] and its importance in the growth of the rat ventral prostate has also been demonstrated [326]. Expression is under the control of androgens and higher in prostatic adenocarcinoma specimens than normal or BPH tissues [326, 327]. In human tissue, VEGF has been found in tumour infiltrating lymphocytes (TILs) and tumour cells themselves [328]. Tumour associated macrophages have been shown in rats transplanted with Dunning MAT-Ly-Lu cell to be the major type of tumour infiltrating cell [329] which can secrete potent inducers of angiogenesis (e.g. Tumour Necrosis Factor alpha, bFGF, VEGF).

A novel angiogenesis inhibitor, angiostatin, was identified in a murine Lewis lung carcinoma and this inhibited the growtl of metastases when released into the circulation by the primary tumour. 
Recently, inoculation of immunodeficient mice with PC-3 cells inhibited neovascularisation of mouse corncas induced by bFGF. This suggests that PC-3 cells also release into the circulation inhibitors of angiogenesis. Whether this reduces metastatic spread is unproven [330].

Inhibitors of angiogenesis such as linomide have been shown to reduce the growth of the primary tumour and metastases of MAT-Ly-Lu cells in vivo $[331,332]$. Linomide reduced the number of tumour infiltrating macrophages and the ability of these cells to produce TNF-alpha [329]. Microvessel density is reduced while apoptosis and necrosis are increased in the TSU and PC-3 tumours in SCID mice treated by linomide [333]. Such treatments may prove beneficial because they increase the death rate without affecting the proliferation rate which is low and partially explains the poor success with cytoloxic chcmotherapy in PC.

Quantifying the extent of angiogenesis in human material has either been performed by analysis of microvessel density or quantifying levels of angiogenic factors in bodily fluids. Microvessel density is assessed by counting the number of vessels in randomly sclected areas aftcr staining for von Willebrand factor antigen [334]. Inter and intra-observer variability is minimised by computer image analysis. Microvessel density has been found to correlate with PSA levels and tumour grade in TURP specimens from patients with PC as well as with the response to cxternal beam radiotherapy [335]. Microvessel density in prostatic tumours is greater than in surrounding benign tissue [334] and can distinguish between primary prostatic tumours from patients with metastases and those without [336]. Using computer image analysis, vessel density distinguished radical prostatectomy specimens with extraprostatic extension from those without [337]. Areas of PIN were distinguished from benign tissue by the number of vessels around the gland perimeter. Assessment of micro-vessel density may prove to be useful in devising selection criteria for those patients most likely to benefit from radical treatments.

As angiogenesis is crucial to the development of tumours, inhibiting it may be an effective treatment. Suramin, a polysulphonated naphthylurea, exerts angiostatic activity in vivo and inhibits the binding of PDGF, bFGF, IGF-1 and VEGF in vitro. It is variably effective in PC $[338,339]$ but with considerable toxicity. Further assessment of potential analogues may identify effective and less toxic substitutes [340]. Levels of bFGF or other angiogenic compounds in the serum or urine may cventually prove useful in the diagnosis or monitoring of treatment in PC [341].

\section{Invasion}

Invasive cells need to penetrate the bascment membrane and interstitial stroma in order to metastasisc. Attachment to the basement mombrane is affected by integrins and expression of specific genes including MMPs is partially regulated through integrin-rclated signals [286]. Proteolysis is needed not only to break through the basement membrane but also for entry into the circulation, extravasation and successful settling at the site of metastasis. Increased motility identifies cells with raised metastatic potential in the Dunning model [342-344] and interference with adhesion can alter motility and slow tumor growth in vivo [345].

\section{Matrix metalloproteinases (MMP)}

The MMPs are a superfamily of homologous metalloendopeptidases that require an intrinsic $\mathrm{Zn}^{++}$for catalytic activity and extrinsic $\mathrm{Ca}^{++}$for enzyme stability. They include gelatinases and collagenases.

Multiple MMPs participate in an enzymatic cascade promoting dissolution of the ECM and tumour invasion. Their activity is controlled either by secretion as an inactive zymogen or by tissue inhibitors of metalloproteinases (TIMP).

MMPs have been shown to be important in invasion in human cell lines and primary tissuc. A PC-3 cell line metastatic to bone (PC-3 ML) contained higher lcvels of MMP-2 compared to its relatively non metastatic precursor [346]. Secretion could be up-regulated by 'invasion stimulating factor' and conversely reduced by IL- 10 with concomitant increases in TIMP-1. [347]. Levels of active MMP-2 were higher and there was almost no TIMP 
in the conditioncel nnedia of primary culturcs of human prostatic cancer tissue [348].

Similarly, matrilysin transfected DU-145 cells are more invasive than controls [349]. J Transcripts for MMP-7 and collagenase type IV were found in the majority of prostatic adenocarcinomas, but collagenase type $I$ and stromelysin I transcripts could not be detected on Northern blots [350]. Using paraffin sections, it was possible to detect MMP-7 and gelatinase $A$ in prostatic epithelial tissue |351]. Levels of TIMP-1 and collagenase are higher in patients with PC than controls [352]. Patients with metastases had greater levels of collagenase than patients without. When combined with TIMP-1 levels, collagenlase was as youd a marker of disease statc as PSA in identifying patients with metastases.

\section{Serine proteinases}

Other degradative enzymes include serine proteases which have a highly reactive serinc residue in their active site and can act independently of MMPs. Urokinase plasminogen activator (U-PA) is a serine protease which cleaves plasminogen activator releasing plasmin that acts on fibrin, fibronectin and laminin. It has been found to have prognostic significance in some tumour systems [353]. U-PA is associated with invasive potential in vivo [354] and is expressed more by PC-3 than LNCaP cells [355].

Other enzymes that degrade the ECM can also release sequestered angiogenic compound such as bFGF. Hyaluronic acid is broken down by hyaluronidase to fragments that promote angiogenesis in vivo. Levels of hyaluronidase are greater in PC tissue than BPH or normal prostate and are associated with the grade of the tumour suggesting that hyaluronidase activity may contribute to the invasive process [322].

\section{Ion channels}

\section{Introduction}

Ion channels are composed of glycosylated transmembrane proteins forming pores in the cell mem- brane that allow the passage of ions down their respective electrochemical gradients [356]. Ion channels are classificd broadly by the principal ion they carry (e.g. $\mathrm{Na}^{+}, \mathrm{K}^{\prime}, \mathrm{Ca}^{++}, \mathrm{Cl}$ ) and by what 'gates' the channels open or close (including changes in membrane voltage, intracellular $\mathrm{Ca}$ " or the binding of nucleotides). The unequal distribution of ions across the cell membrane results in the generation of the membrane potential, which is about 100000 volts per centimetre. The positional conformation of charged molecules near the cell membrane will he affected by this potential [357]. More recently, ion channels have bcen implicated in the cell cycle [358-361] apoptosis $[360,362]$, cell adhesion [363$365]$, cell movement $[363,366,367]$, exocytosis [ 368 , $369]$, proliferation $[358,361,370]$ and multidrug resistance $[371,372]$; all of which have direct relevance to the neoplastic process.

Bricfly, to identify ion channels either the membrane voltage or current flow are fixed and then deliberately changed whilst continuously monitoring the other. This allows the measurement of current flow across open channels. Using the patch clamp technique, for which Neher and Sakmann were awarded the Nobel Prizc in 1991 [373], it became possible to study channels present in low density, in areas difficult to clamp or of low conductance and in real time.

\section{Invasion}

The first systematic examination of cell membrane ion channels with respect to known malignant phenotype was made in the Dunning model of PC. AT-2 cells which are invasive but not metastatic were compared with MAT-LyLu cells which are invasive and metastatic in vivo [374]. MAT-LyLu cells were found to have voltage-activated sodium channels (VASC) in about $50 \%$ of cells, which borc characteristics similar to neuronal type VASC. Voltageactivated $\mathrm{K}^{\prime}$ channels (VAKC) were found in AT-2 cells, but $\mathrm{K}^{-}$current was twice as great as in MATLyLu cells. When VASCs were blocked by tetrodotoxin (TTX) (which is a specific blocker of VASCs), invasion was reduced significantly in vitro. Further work in human cell lines has supported a role for 
VASC in tumour invasion. When LNCaP and PC-3 cells were evaluated, VASCs were found only in $\mathrm{PC}-3$ cells and $\mathrm{K}^{+}$currents were considerably larger in LNCaP cells $[375,376]$. Again the incorporation of TTX significantly reduced invasion in vitro. PC-3 cells were also more depolarised by a median of $5 \mathrm{mV}$ (CI 0 to 11) compared to LNCaP cells. Similar observations were made when mombrane potentials from cells of human infiltrating ductal breast carcinoma were compared to cells from non-malignant breast tissue [377]. Membranc potential has been shown to change dianatically through the cell cyclc [359] and blocking $\mathrm{K}^{-}$channels can induce cell-cycle arrest $[358,370]$.

The importance of membrane ion channels may relate to the factors described above, but also to cell movement: Lransformed Madin-Darby Canine Kidney (MDCK-F) cells show directional migration depending on the position of $\mathrm{K}_{\mathrm{Ca}}$ channels in the membrane [379] which may further mediate migration/invasion. In neurones, relcase of neurotransmitters contained within vesicles can occur upon membrane depolarisation and similar mechanisms could lead to the rclease of MMPs or serine proteinases in tumour cells.

\section{Calcium, androgens and apoptosis}

Programmed cell death (apoptosis) occurs following androgen withdrawal in androgen dependent PC cell lines. There is rise in $\mathrm{Ca}_{i}$ which activates $\mathrm{Ca}^{1} / \mathrm{Mg}^{++}$-dependent endonucleases present within the nucleus and fragments DNA initiating the programmed cell death sequence [380, 381]. Androgen-independent cells do not undergo an clevation in $\mathrm{Ca}^{2}$ after androgen withdrawal, but prevention of re-uptake of $\mathrm{Ca}^{1+}$ in to the sarcoplasmic reticulum by thapsigargin (TG) will induce apoptosis. This induces an carly rise in intracellular $\mathrm{Ca}_{\mathrm{i}}{ }^{++}$which probably originates from the endoplasmic reticulum and a prolonged further rise which most likely depends on the entry of $\mathrm{Ca}^{++}$through $\mathrm{Ca}^{+\tau}$ channels in the cell membrane [382]. In normal rat ventral prostate verapamil, a blocker of L-type voltagc-activated $\mathrm{Ca}^{++}$channels, prevents prostate tissue regression following androgen withdrawal, suggesting a puta- tive role for voltage-aclivated $\mathrm{Ca}^{++}$channels in the cell membrane [383]. The bcl-2 protein helps prevent cells from undergoing apoptosis and confers protection against elevations in $\mathrm{Ca}_{\mathrm{i}}^{++}$as recently demonstrated in PC-3 cells transfected with the $\mathrm{Bcl}-2$ gene [384]. Androgen exposure raises $\mathrm{Ca}_{i}^{++}$in LNCaP cells to similar levels as seen in the later stages of androgen-independent cells treated by TG $[382,385]$. The rise in $\mathrm{Ca}^{++}$can be blocked by $1 \mathrm{mM}$ verapamil which also suggests that $\mathrm{Ca} \cdot \mathrm{ch}$ chnels are present [385]. These results suggest that the I lationslip between $\mathrm{Ca}^{\prime}$ ', androgens and apoptosis is complex and merits further investigation.

\section{Proliferation}

It is known that progression through the cell cycle is $\mathrm{Ca}^{1+}$ dependent in certain tissues [361] and there is evidence that $\mathrm{Ca}^{+-}$channels are important in the proliferation of prostatic cells. Maximum growth rates of DU-145 cells are dependent on extracellular $\mathrm{Ca}^{-+}$concentration [386]. Depolarisation of these cells by high extcrnal $\mathrm{K}^{+}$results in $\mathrm{Ca}^{\prime}$ ' entry which suggests the presence of voltage-activated $\mathrm{Ca}^{++}$channels. Verapamil caused a reduction in cell growth with an $\mathrm{IC}_{50}$ of $55 \mathrm{mM}$ but increased ${ }^{45} \mathrm{Ca}^{++}$ intake. Verapamil blocks $\mathrm{K}^{\prime}$ channels with an $\mathrm{IC}_{50}$ in the range 50 to $150 \mathrm{mM}$ in $\mathrm{LNCaP}$ and $\mathrm{PC}^{-}-3$ cells when tested using the whole-cell configuration of the patch clamp technique, and the cells die within days when grown with verapamil at these concentrations (our unpublished observations). It is possible that DU-145 cells were depolarised under such conditions allowing the entry of $\mathrm{Ca}^{++}$through voltage-activated $\mathrm{Ca}{ }^{\prime *}$ channels. Studies in other cell lines with a similar respone have suggested that extracellular $\mathrm{Ca}^{++}$is not the origin of the rise in $\mathrm{Ca}_{i}{ }^{\prime \prime}$ and that there may be alternative mechanisms by which verapamil excrts its biological effects.

There is cvidence in various tissues that growth factors elevate intracellular $\mathrm{Ca}^{++1}$ via membrane channels, but such an effect has not yet been demonstrated in prostatic tissue. It is likely that such ionic responses are essential to the transduction of growth factor signals because similar responses have been found in ccll lines from the embryonic zebra fish and 
this suggests that these have been conserved through evolution [387]. Entry of $\mathrm{Ca}^{-1}$ through voltage-activated channels results in the phosphorylation of the serum response factor (SRF) that activates the serum response clement of the c-fos gene. The latter is important in growth factor induced transcription [388]. In Balb/c 3T3 cells, IGF-2 directly stimulates $\mathrm{Ca}{ }^{1-}$ influx in cells primed with EGF or PDGF independent of mombrane voltage but not if cells are in $\mathrm{G}_{0}$ [389]. A calcium channel accelerates progression through $G_{1}$ in the presence of IGF-2 such that priming with EGF or PDGF becomes less important [390)]. $\mathrm{K}_{\mathrm{C}_{2}}$ channels are induced following exposure to EGF and PDGF and this has been shown in murine fibroblasts to depend on $\mathrm{p} 21$ ras and raf kinase [391]. Such channcls are present in PC-3 cell lines [376]. Furthermore, inhibition of $\mathrm{K}_{\text {ATP }}$ channels causes reversible cell cycle arrest in breast cancer cell lines. Such studies indicate that $\mathrm{K}^{-}$ channels and $\mathrm{Ca}^{-\cdots}$ have important roles in translating extracellular messages to intracellular signals.

\section{Prohlem areas and focal issues}

It remains to bo scen whether the hypothesis in the Dunning and human cell lines are borne out when more ecll lines or indecd human tissue are examined. Specific studies focused on identifying $\mathrm{Ca}^{{ }^{++}}$ channels need to be carried out as these may well be pivotal in exerting local effects. Cloning of ion channels and transfection studies will indicate more clcarly the importance of ion channels both in vitro and in vivo.

\section{Concluding remarks}

PC still poses many questions regarding its actiology, pathology including definition, pathogenesis and clinical management. It is evident from this review that $P C$ has been underinvestigated but as a direct consequence of recent public awareness there has been a stimulus to undertake fundamental research. (This covers early detection of PC so that treatments may be effective.) Perhaps more importantly, we need to identify those features which distinguish PC from other solid cancers. There is an apparent rush to repeat studies carried out on other solid tumours such as breast, colorectal or pancreatic - this may prove to be short sighted and unrewarding. The natural history of this enigmatic disease is rather different from most other solid tumours and therein may lie the key to unravelling its biologic mysteries. Some clues will be gained by studying the genes most frequently involved in $P C$, and the cytogenetic analyses are an important starting point to locate areas of gross genetic damage. Increased clinical effort in locating potential PC families would be a major help in identifying a PC gene and may well require international collaboration. In addition, the reasons for the differences in prevalence of PC among differing cultural groups may wcll reveal an important facet controlling the pathogenesis of $\mathrm{PC}$.

The other arcas which are distinctive to $\mathrm{PC}$ are the mechanisms underlying hormone regulation of cell growth and progression, and the development of novel anti androgenic therapies will be helpful. It is essential to understand the mechanisms underlying the phenomenon of resistance to androgen blockade in order to circumvent this problem; at the present time reduction of the androgenic drive is an effective management strategy but the effcct is temporary. The other feature that characterises $\mathrm{PC}$ is the nature of the induced stroma. This is particularly rclevant in metastatic disease where a fibrocollagenous response may dominatc the histological picture. Factors produced by the tumour in bone metastasis causc bone matrix destruction and replacement by sclerotic stroma, resulting in debility and pain. If this response can be controlled, it may allow patients to live with their discase, prolonging quality and quantity in life. In PC, effective management and reduction of symptoms may be a more realistic and desirable aim than attempting to search for a cure for this discase.

\section{Key unanswered questions}

These are

1) What are the mechanisms underlying the development of resistance to androgen blockade?

2) What are the principal genes most frequently involved in $\mathrm{PC}$ ? 
3) Which genes govern the progression of $\mathrm{PC}$ from latent to aggressive and metastatic cancer?

4) What factors govern the development of the stromal response in $\mathrm{PC}$ ?

5) How does the desmoplastic response modulate the growth of PC?

6) What are the factors underlying PC metastasis, particularly to bone?

7) Are there other serum markers which may be more discriminatory than PSA for distinguishing between latent and aggressive cancer?

8) What are the functions of PSA, PSM, PAP on prostatic epithelial cell growth and differentiation?

9) What factors govern successful propagation and maintenance of primary PC cell lines and immortalisation of benign prostatic epithelia?

10)Development of in vitro models more relevant to in vivo disease.

\section{Acknowledgements}

The authors wish to thank Dr Gordon Stamp and Dr Andrew Stubbs for critically reading the manuscript and for the many useful suggestions. This work has been supported by a grant from the Medical Research Council.

\section{References}

1. Woolf $\mathrm{SH}$ : Screcning for prostate cancer with prostate-specilic antigen. An examination of the evidence. [Revicw]. N Engl J Med 333: 1401-1405, 1905

2. Parkin DM, Pisani P. Ferlay I: Estimates of the worldwide incidence of 18 major cancers in 1985 . Int J Cancer 54: 594606,1993

3. Boyle P, Maisonneuve P, Napalkov P: Incidence of prostate cancer will double by the year 2030: the argument for. Eur Urol 29 (Suppl 2): 3-9, 1996

4. Jensen OM, Esteve J, Moller H, Renard H: Cancer in the European Community and its member states. Eur $\mathrm{J}$ Cancer 25: $1167-1256,1990$

5. Boring CC, Squires TS, Tong T: Cancer Statistics CA Cancer J Clin 44: 7-26, 1994

6. Boyle P, Maisonneuve P, Napalkov P: The threat to health and strategies for control. In: Peeling WB (ed) Questions and Uncertainties aboul Prostate Cancer, pp. 3-29, OxCord: Blackwell Science. 1996
7. Parker SL, Iong T, Bolden S. Wingo PA: Cancer Statistics 1996. CA. Cancer J Clin. 1996

8. Schroder FH, Boyle P: Screening for prostatc cancer - necessity or nonsense? [Review| Fur I Cancer $29 \wedge: 656.661$. 1993

9. Potosky AI, Miller BA, Albertsen PC, Kramer BS: The role of increasing detection in the rising incidence of prostate cancer. JAMA 273: 548 552, 1995

10. Walsh PC: Using prostatc-specific antigen to diagnose prostate cancer: sailing in uncharted waters [editorial; connnen1] [sce cunnuents]. Ann Intern Med 119: 948-949, 1993

11. Hall RR: Screcning and early detection of prostate cancer will decrease morbidity and mortality from prostate cancer: the argument against. Eur Urol 29 (Suppl 2): 24- 26, 1996

12. Kramer BS, Brown ML, Prorok PC, Potosky AL, Gohagan JK: Prostate cancer screening: what we know and what we need to know. Ann Intern Med 119: 914 923, 1996

13. Hacnszel W, Kurihara M: Studies ol Japanese migrants. I. Mortality from cancer and other discases among. Japanese in the United States. Natl Cancer Inst Monogr 40: 43-68. 1996

14. Anonymous: Primer on molecular control of prostate cancer growth. New Jersey: Whitchouse Station, Mcrck, 1994

15. Giovannucci E, Rimm FB, Coldiz GA, Stampler MJ, Ascherio A, Chute CC. Willett WCA: A prospective study of dietary tat and risk of prostate cancer [see comments]. J Natl Cancer Inst 85: 1571-1579, 1993

16. The alpha-tocopherol, beta-carotene cancer prevention study group. The effeet of vitamin F and beta-carotene an the incidence of lung cancer and other cancers in male smokers. N Engl J Med 330: 1029-1035, 1994

17. Corder EH, Guess HA, Hulka BS, Friedman (jD, Sadler M, Vollmer RT, I obaugh B, Drezner MK, Vogelman JH, Orentrcich N: Vitamin D and prostate cancer: a prediagnostic study with stored sera [see comments]. Cancer Lpidemiol Biomarkers Prev 2: 467-472. 1993

18. Morrison H, Savitz D, Semenciw R, I lulka B, Mao Y, Morison $\mathrm{D}$, Wigle $\mathrm{D}$ : Farming and prostate cancer mortality [see comments] Am I Fpideminl 137:270-280. 1993

19. Dosemeci M, I Hoover RN, Blair A, Figgs IW, Devesa S, Grauman D, Fraumeni JF Jr: Farming and prosiate cancer among African-Americans in the southeastern Lnited Statcs. J Natl Cancer Inst 86: 1718-1719, 1994

20. Ekbom A. Hsieh CC, Lipworth L, Wolk A, Ponten J, Adam HO, Trichopoulos D: Perinatal characteristics in relatiun to incidence of and mortality from prostate cancer. Br Med J 313: 337-341, 1996

21. Whitmorc WF Jr: Natural bistory of low-stage prostatic cancer and the impact of early detection. Urol Clin North Am 17: 689-697, 1990

22. Young $\mathrm{HH}$ : The early diagnosis and radical cure of carcinoma of the prostate; being a study of 40 cases and presentation of a radical operation which was carried out in 4 cases. Bull Johns Hopkins Hosp 16: 315-318, 1905 
23. L.u-Yao Gl, Grenberg ER: Changes in prostate cancer incidence and treatment in USA [see comments]. Lancet 343: 251-254, 1994

24. Williams (3: Radical prostatectomy in localised prostate cancer. In: Waxman J, Williams G (cds) Urological Oncology, I.ondon: Fdward Arnold. 1992

25. Breslow $\mathrm{X}$, Chan CE, Dhom G, Drury RAB, Frank LM, Gellei B, Lee YS, Lundberg S, Sparke B, Sternby VII, Tulinius $\mathrm{H}$ : Jatent carcinoma of the prostate at autopsy in 7 areas. Int I (ancer 20; 680-688, 1996

26. Schroder FH: Detection of prostate cancer [editorial] [see comments]. Br Med J 310: 140 141, 1995

27. Ayala AG, Ro JY, Babaian R, 'Troncoso P, Grignon DJ: 'The prostatic capsule: does it cxist? lts importance in the staging and treatment of prostatic carcinoma. Am J Surg Pathol 13: 21-27, 1989

28. McNeal JE: Normal histology of the prostate. Am J Surg Pathol 12: 619-633, 1988

29. McNeal JE, Bostwick DG: Anatomy of the prostate: implications for disease. In: Bostwick DG (ed) Pathology of the Prostate, pp. 1-14, New York: Churchill Livingstone. 1990

30. McNeal JF: Origin and development of carcinoma in the prostate. Cancer 23: 24 34, 1969

31. Allsbrook WC Jr, Simms WW: Histochemistry of the prostate [see comments]. [Review]. Hum Patho] 23: 297-305, 1992

32. I.eong $\wedge \mathrm{S}$, Gilham $\mathrm{P}$, Milos $\mathrm{J}$ : Cytokeratin and vimentin intenuediate lilannent proteins in benign and neoplastic prostatic epithelium. Histopathology 13: 435-442, 1988

33. Ruizeveld de Winter J $\Lambda$, Janssen PJ, Sleddens HM, Verleun-Mooijman MC. Trapman J, Brinkmann AO. Santerse AB, Schroder $\mathrm{FH}$, Van der Kwast TH: Androgen receptor status in localized and locally progressive hormone refractory human prostate cancer. Am J Pathol 144: 735-746. 1994

34. Cunha GR, Donjacour AA. Cooke PS, Mee S, Bigsby RM, Higgins SJ, Sugimura Y: The endocrinology and developmental biology of the prostate. [Revicw]. Endoer Rev 8; $338-362,1987$

35. Bonkhoff $\mathrm{H}$, Stein U, Remberger K: Multidirectional diflerentiation in the normal, hyperplastic, and neoplastic human prostatc: simultancous demonstration of cell-specific epithelial markers. Hum Pathol 25: 42-46, 1994

36. Gown A.M, Vogel AM: Monoclonal antibodies to human intermediate filament proteins: distribution of filament proteins in normal human tissues. Am J Pathol 114: 309321,1984

37. Hedrick L, Epstein JI: Use of keratin 903 as an adjunct in the diagnosis of prostate carcinoma. Am J Surg Pathol 13: 389-396, 1989

38. O'Malley FP, Grignon DJ, Shum DT: Usefulness of immunoperoxidase staining with high-molecular-weight cylokcratin in the differential diagnosis of small-acinar lesions of the prostate gland. Virchows Arch A Pathol Anat Histopathol 417: 191-196, 1990

39. Kramer CE, Epstcin JI: Nuclcoli in low-grade prostate adenocarcinoma and adenosis. Ilum Pathol 24: 618-623, 1993

40. Collina (;, Botticelli AR, Martinelli AM, Fano RA., Trentini (jP: Sclerosing adenosis of the prostate. Report of 3 cases with clectronmicroscopy and immunohistochemical study. Histopathology 20: 505-510, 1992

41. Kahane H. Sharp JW, Shuman GB, Dasilva G, Epstein JI: Utilization of high molecular weight cytokeratin on prostate needle biopsies in an independent laboratory. Urology 45: 981-986, 1995

12. Howat $\Lambda J$, Mills PM, Lyons IJ, Stephenson 'TJ: $A$ bsence ol S-100 protein in prostatic glands. Histopathology 13: 468470,1988

43. Srigley JR, Dardick I. Hartwick RW. Klotz LH: Basal epithelial cells of human prostate gland are not myoepithelial cells. A comparative immunohistochemical and ultrastructural study with human salivary gland. Ann J Pathol 136: 957-966, 1990

44. Bonkhoff $\mathrm{H}$, Remberger K: Widespread distribution of nuclear androgen receptor in the basal cell layer of the normal and hyperplastic human prostate. Virchows Arch A Pathol Anat Histopathol 422: 35-38, 1993

45. Chodak GW, Kranc DM, Puy LA, Takeda H, Johnson K. Chang $\mathrm{C}$ : Nuclear localization of androgen receptor in heterogeneous samples of normal, hyperplastic and neoplastic human prostate. J Urol 147: 798-803, 1992

46. Cohen RJ, Glezerson G, Taylor LF, Grundle HA, Naude JH. The neuruendedine cell pepulation of the lsunan prostate gland. J Urol 150: 365-368, 1993

47. Abrahamsson PA, di Sant' $\wedge$ gnese PA: Neuroendocrine cells in the human prostate gland. [Review]. .J Androl 14: 307-309, 1993

48. Aprikian AG, Cordon-Cardo C, Fair WR, Reuter VE: Characterization of neurocndocrine differentiation in human benign prostate and prostatic adenocarcinoma. Cancer 71: 3952-3965, 1993

49. di Sant'Agnese PA, de Mesy Jensen KL, Churukian CJ, Agarwal MM: Human prostatic endocrinc-paracrino (APUD) cells. Distributional analysis with a comparison of serotonin and neuron-specific cnolase immunoreactivity and silver stains. Arch Pathol Lab Med 109; 607-612, 1985

50. Davis NS, di Sant'^gnese PA, Fwing JF, Mooney RA: The neuroendocrine prostate: characterization and quantitation of calcitonin in the human gland. J Urol 142: $884-888$, 1989

51. Bonkhoff H, Stein U, Remberger K: Androgen receptor status in endocrine-paracrine cell types of the normal, byperplastic, and neoplastic human prostate. Virchows Arch A Pathol Anat Histopathol 423: 291-294, 1993

52. Noordzij M $\Lambda$. Van Steenbrugge GJ, Van der Kwast TH, Schroder FH: Neuroendocrine cells in the normal, hyperplastic and neoplastic prostate. [Review]. Urol Res 22: 333-341, 1995

53. di Sant Agnese PA: Neuroendocrine differentiation in the precursors of prostate cancer. Eur Urol 30: 185-190, 1996 
54. Kabalin JN, Peelıl DM, Stancy TA: Clonal growth of human prostatic epithelial cells is stimulated by fibroblasts. Prostate 14: 251. 263, 1989

55. Chung IW. Gleave ME, Hsich JT, Hong SI. Zhau HE: Reciprocal mesenchymal-epithelial interaction affecting prostate tumour growth and hormonal responsiveness. [Revicw]. Cancer Surv 11: 91-121, 1991

56. Cunha GR, Chung LWK, Sannon JM, Taguihi O, Fujii H: Hormone induced morphogenesis and growth: role of mesenchymal interactions. Recent Prog Horm Res 39; 559$598,19 \% 3$

57. Cunha GR. Chung IWK: Stromal epithelial interaction. Induction of prostate phenotype in urothelium of testicular feminized (IFm/y) mice. J Steroid Biochem 14: 13171312,1981

58. Cunha GR: Epithelial stromal interactions in the development of the urogenital tract. Int Rev Cylol 47: 137-194, 1976

59. Bostwack DG: Is the behaviour of prostate cancer understood? ln: Pecling WB (ed) Questions and Uncertainties about Prostate Cancer, pp. 30-49. Oxford: Blackwell Science. 1906

60. Bostwick DG: Progression of prostatic intracpithclial neoplasia to early invasive adenocarcinoma. Fur Urol 30: 145152,1996

61. Epstein J1, Grignon DJ, Humphrey PA, McNeal JE, Scsterhenn IA, Troncoso P, Whecler TM: Interobserver reproducibility in the diagnosis of prostatic intracpithelial neoplasia. Am J Surg Pathol 19: 873-886, 1995

62. Raviv G, Janssen T, Zlotta AR, Descamps F, Verhest A, Schulman CC: Prostatic intraepithelial neoplasia: influenco of clinical and pathological data on the detection of prostate cancer. J Lrol 156: 1050-1055, 1996

63. Bostwick DG, Cooner WH, Denis L, Jones GW, Scardino PT, Murphy GP: The association of benign prostatic hyperplasia and cancer of the prostate. [Review]. Cancer 70: 291-301. 1992

64. Bostwick DG: H ligh grade prostatic intraepithelial neoplasia (PIN). the most likely precursor of prostate cancer. Cancer 75: 1823-1836, 1993

65. Sakr WA, Haas GP, Cassin BF, Pontes JE, Crissman JD: The frequency of carcinoma and intraepithelial ncoplasia of the prostate in young male paticnts [sce comments]. J Urol 150: 379-385, 1993

66. Baretton GB, Vogt T, Blasenbreu S, Lohrs U: Comparison of DNA ploidy in prostatic intraepithelial ncoplasia and invasive carcinoma of the prostate: an image cytometric study. I Ium Pathol 25: 506-513, 1994

67. Crissman JD, Sakr WA, Hussein ME, Pontes JE: DNA quantitation of intracpithelial neoplasia and invasive carcinoma of the prostate. Prostate 22: 155-162, 1993

68. Weinberg DS, Weidner N: Concordance of DNA content between prostatic intracpithelial neoplasia and concomitant invasive carcinoma. Evidence that prostatic intracpithelial neoplasia is a precursor of invasive prostatic carcinoma. Arch Pathol Lab Med 117: 1132-1137, 1993

69. Arends MJ. Bird CC: Recombinant DNA technology and its diagnostic applications. Histopathology 21:303 313, 1992

70. Crocker J: Molccular biology in hislopathology. Chichester: John Wiley and Sons, 1994

71. Grody WW, Gatti RA, Naein F: Diagnostic molecular pathology. Mod Pathol 2: 553-568, 1989

72. Rowley JD, Aster JC, Sklar J: The impact of new DNA diagnostic technology on the management of cancer patients. Survey of diagnostic techniques. Arch Pathol Lab Med 117: 1104 1109, 1993

73. Sklar J: DNA hybridization in diagnostic pathology. Hum Pathol 16: 654-658, 1985

74. Molecular techniques in diagnostic pathology. Hum Pathol 25: 555-614, 1994

75. Lee C, Shevrin DH, Kozlowski JM: In vivo and in vitro approaches to study mctastasis in human prostatic cancer. [Revicw]. Cancer Metastasis Rev 12: 21-28, 1993

76. Isaacs JT, Isaacs WB, Feilz WW, Scheres J: Establishment and characterization ol seven Dunning rat prostatic cancer cell lines and their use in developing methods for predicting metastatic abilities of prostatic cancers Prostate 9: 2.61. 281,1986

77. Hedlund TE, Mollatt KA, Miller GJ: Stable expression of the nuclear vitamin D receptor in the human prostatic carcinoma cell line JCA-1: evidence that the antiprolilerative effects of 1 alpha. 25-dihydroxyvitamin D3 are mediated exclusively through the genomic signaling pathway. Endocrinulugy 137. 1554-1561, 1996,

78. Naghashfar Z, DiPaolo JA, Woodworth CD, Passaniti A: Immortalization of human adult prostatic adenocarcinoma cells by human papilloma virus HPV16 and -18 DNA. Cancer Lett 100: 47--54, 1996

79. Horoszewicz JS, Leong SS, Kawinski E, Karr JP, Rosenthal $H$, Chu 'IM, Mirand FA, Murphy GP: LNCaP model of human prostatic carinoma. Cancer Res 43: 1909-1818, 1983

80. Murakami YS, Albertsen H, Brothman AR, Leach RJ, Whitc RL: Suppression of the malignant phenotype of hu man prostatic cancer cell line PPC-1 by introduction of normal fragments of human chromosome 10. Cancer Res 56 : 2157-2160, 1996

81. Hurkadli KS, Lokeshwar B, Sheth AR, Block NL: Detection of prostatic-inhibin-like peptide in the cyloplasm of LNCaP cells, a human prostatic adenocarcinoma cell line. Prostate 24: $285-290,1944$

82. Israeli RS, Powell CT, Corr JG, Fair WR, Heston WD: Expression of the prostate-specific membrane antigen. Cancer Res 51: 1807-1811, 1904

83. Furr BJ, Tucker H: The preclinical development of bicalutamide: pharmacodynamies and mechanism of action Urology 47: 13-25; discussion 29-32, 1996

84. Taplin M-E, Bubley GJ, Shuster TD, Frantz ME, Spooner AE, Ogata GK, Keer HN, Balk SP: Mutation of the androgen-rcceptor gene in metastatic androgen-independent prostate cancer. N Engl J Med 332: 1393-1398, 1995

85. Lee C, Shevrin DH, Korlowski JM. In vivo and in vitro ap- 
prouches to study metastasis in human prostatic cancer [Revicw]. Cancer Metastasis Rev 12: 21-28. 1993

86. Kaighn ME, Narayan KS, Ohnuki Y, I echner JF, Jones LW: Establishment and characterization of a human prostatic carcinoma cell line (PC-3). Invest Urol 17: 16-23, 1979

87. Garde SV, Sheth AR, Porter AT, Pienta KJ: A comparative study on expression of prostatic inhibin peptide, prostate acid phosphatase and prostate specitic antigen in androgen independent human and rat prostate carcinoma cell lines. Cancer Lett 70: 159-166, 1993

88. Stearns ME, Wang M, Stearns M: II.-10 blocks collagen IV invasion by 'invasion stimulating factor' activated PC-3 MI cells: upregulation of TIMP-1 expression. Oncol Res 7 : $157-163,1995$

89. Bishop JM: Molecular themes in oncogenesis. Cell 64: 235248,1996

90. Lisitsyn N, Wigler M: Cloning the differences between 2 complex genomes. Science 259: 946-951, 1993

91. Dong J'l, Lamb PW, Rinker-Schaeffer CW, Vukanovic J, Ichikawa T, Isaacs JT, Barrett JC: $K A / 1$, a metastasis suppressor gene for prostate cancer on human chromosnme 11p11.2. Science 268: 884-886, 1995

92. Berthon P, Dimitrov T, Stower M, Cussenot O, Mailland NJ: A microdissection approach to detect molccular markers during progression of prostate cancer. Br J Cancer 72 : 946-951, 1995

93. Innis MA, Gelfand GH, Sninsky JJ, White TJ; PCR protocols, a guide to methods and applications. San Diego, California: Academic Press, 1990

94. Jackson V: Studies on histone organization in the nucleosome using formaldehyde as a reversible cross-linking agent. Cell 15: 945-954, 1978

95. Yasui W, Ito H. Tahara E: DNA analysis of archival material and its application to tumour pathology. Diagnostic molecular pathology. A practical approach. Oxford: IRL Press, 1992

96. Eisenberg M, Chimera J $\Lambda$ : Human identification by DNA analysis. Diagnostic molecular pathology. A practical ap proach. Oxford: IRL Press, 1992

97. Orita M, Suzuki Y, Sekiya T, Hayashi K: Rapid and sensilive detection of point mutations and DNA polymorphisms using the polymerase chain reaction. Genomics 5: $874-879,1989$

98. Orita $\mathrm{M}$, Iwahana $\mathrm{H}$, Kanazawa $\mathrm{H}$, Hayashi $\mathrm{K}$, Sekiya $\mathrm{T}$ : Detection of polymorphisms of human DNA by gel electrophoresis as single-strand conformation polymorphisms. Proc Natl Acad Sci USA 86: 2766-2770, 1989

99. Gall YG. Pardue ML: Formation and detection of RNADNA hyrid molecules in cytological preparations. Proc Natl Acad Sci USA 63: 378-383, 1969

100. Herrington S, Mc(jee JO: Diagnostic molecular pathology: A practical approach. In: Herrington CS, McGee JO (eds) Principles and Basic Methodology of DNA/RNA Detection by in situ Hybridization, pp. 69-102, Oxford: IRL Press, 1992

101. Trent JM: Clinical correlations of chromosome change in human solid tumors: the tip of the iecberg? J Natl Canecr Inst 81: 1874 1878, 1989

102. Sandberg AA, Iurc-Carel C., Gemmill RM: Chromosomes in solid tumors and beyond. Cancer Res 48: 1049.1059.1988

103. Morrison L, Legator M: Multicolor in situ hybrictisation using direct labelled fluorescent probes. Clin Chem 39: 733734,1993

I04. Alcara\% A, Iakahashi S, Brown JA, Herath Jf, Bergstralh EJ, Larson-Keller JJ, Licber MM, Jenkins RB: Aneuploidy and aneusomy of chromosome 7 detected by fluorescence in situ hybridization are markers of poor prognosis in prostate cancer. Cancer Res 54: 3998-4002, 1994

105. Mullis KB, Faloona FA: Specific synthesis of DNA in vitro via a polymerasc-catalyzed chain reaction. Methods Enzymol 155: 335-350, 1987

106. McPherson M.J, Quirke P. Taylor (GR (eds): PCR. A practical approach. Oxford: IRL Press, 1991

107. Brothman AR. Peehl DM, Patel AM, McNeal JE: Frcquency and pattern of karyotypic abnormalities in human prostate cancer. Cancer Res 50: 3795 3803, 1990

10 Konig II. 'Tenhel W. Van I ongen IW, Hagemeijer A, Ramijn JC, Schroder FH: Tissue culture loss of ancuploid cells from carcinomas of the prostate. Genes Chromosom Cancer 8: 22-27, 1993

109. Micale MA, Mohamed A, Sakr W, Powell IJ, Wolman SR: Cytogenetics of primary prostatic adenocarcinoma. Clonality and chromosome instability. Cancer Genet Cylogenet $61: 165-173,1992$

110. Bandyk MG, Zhao L, Troncoso P, Pisters LL, Palmer JL, von Eschenbach AC, Chung LW, Liang JC: 'Irisomy 7: a potential cytogenetic marker of human prostate cancer progression. Genes Chromosom Cancer 9: 19-27, 1994

111. Takahashi S, Shan AL. Ritland SR, Delacey KA, Bostwick DG, Licber MM, Thiobideau SN, Jenkins RB: Frequent loss of heterozygosity at $7 \mathrm{q} 31.1$ in primary prostate cancer is associated with lumor aggressiveness and progression. Cancer Res 55: 41.14-4119, 1995

112. Carter BS, Ewing CM, Ward WS, Treiger BF, Aalders I'W, Schalken JA, Epstein JI, Isaacs WB: Allelic loss of chromosomes $16 \mathrm{q}$ and $10 \mathrm{q}$ in human prostate cancer. Proc Natl Acad Sci USA 87: 8751-8755, 1990

113. Kunimi K, Bergerheim US, Larsson IL, Ekman P, Collins VP: Allclotyping of human prostatic adenocarcinoma. Genomics 11: 530-536, 1991

114. Bergerheim US, Kunimi K, Collins VF, Ekman I': Deletion mapping of chromosomes 8,10 , and 16 in human prostatic carcinoma. Genes Chromosom Cancer 3: 215-220, 1991

115. Bova GS, Carter BS, Bussemakers MJ, Emi M, Fujiwara Y, Kyprianou N, Jacobs SC, Robinson JC, Epstein JI, Walsh PC et al.: Homozygous deletion and frequent allelic loss of chromosome $8 \mathrm{p} 22$ loci in human prostate cancer. Cancer Res 53: 3869-3873, 1993

116. MacGrogan D, Levy A, Bostwick D, Wagner M, Wells D, Bookstein R: Loss of chromosome arm 8 p loci in prostate cancer: mapping by quantitative allelic inbalance. Genes Chromosom Cancer 10: 151-159, 1994 
117. Macoska JA, Trybus TM, Sakr WA. Woll MC, Benson I'I), Powell IJ, Pontes JE: Fluorescence in situ hybridization analysis of $8 \mathrm{p}$ allelic loss and chromosome 8 instability in human prostute cancer. Cancer Res 54: 3821 3830, 1904

118. Vocke CD, Pozzatti RO, Bostwick DG. Florence CD, Jennings SB, Srup SE, Duray PH: Analysis of 99 microdissected prostate carcinomas reves a high frequency of allelic loss on chromosome 8p 12-21. Cancer Res 56: 24111-24126, 1996

119. Emmert-Buck MR, Vocke CD, Pozzatti RO, Duray PH, Jennings $\mathbf{S B}$, Florence $C D, \angle$ huang 7 . Bostwick DG, Liotta LA, Yinchan WM: Allelic loss on chromosome 8 p12-21 in microdissected prostatic intracpithelial neoplasia. Cancer Res 55: 2059-2062, 1995

120. Trapman J, Sleddens HF, Van der Weiden MM, Dinjens WN, Konig JJ, Schroder FH, Faber PW, Bosman FT: Loss of heterozygosity of chromosome 8 microsatellite loci implicates a candidate tumor suppressor gene between the loci D8S87 and D8S133 in human prostate cancer. Cancer Res 54: 6061-6064, 1994

121. Brothman AR, Patel AM: Characterization of 10 n1ta ket chromosomes in a prostatic cancer cell line by in situ hybridization. Cylogenet Cell Genet 60: 8-11, 1992

122. Murakami YS Alhertsen H, Brothman AR. Leach RJ. White RL: Suppression of the malignant phenotype of human prostate cancer cell line PPC-1 by introduction of normal fragments of human chromosome 10. Cancer Res 56: 2157-2160, 1996

123. Deitch AD, De Vere White RW: Hlow cytometry as a prediclive modality in prostate cancer. [Review]. Hum Pathol 23. 352-359, 1992

124. 'Tribukait B: Flow cytometry in assessing the clinical aggressiveness of genito-urinary neoplasms. World J Urol 5: 108-122. 1996

125. Falkmer UG: Methodologic sources of errors in image and flow cytometric DNA assessments of the malignancy potential ol prostatic carcinoma. [Revicw]. Hum Pathol 23: 360--367, 1992

126. Jones EC, McNeal I, Bruchovsky N, De Jong G: DNA content in prostatic adenocarcinoma. A flow cytometry study of the predictive value of aneuploidy for tumor volume, percentage Gleason grade 4 and 5 , and lymph node metastases. Cancer 66: 752-757, 1990

127. Bos IL: Ras oncogenes in human prostate: revicw. Cancer Res 49: 4682-4689, 1989

128. Barbacid M: Ras oncogenes: their role in neoplasia. Eur J Clin Invest 20: 225-235, 1990

129. Peehl DM: Oncogenes in prostate cancer. An update. |Review]. Cancer 71: 1159-1164, 1993

130. McCormick F; Activators and eflectors of ras p21 proteins. Curr Opin Genet.Lev 4: 71-76, 1994

131. Pergolizzi RG, Kreis W, Rottach C, Susin M, Broome JD; Mutational status of codons 12 and 13 of the $\mathrm{N}$ - and $\mathrm{K}$-ras gencs in tissue and cell lines derived from primary and metastatic prostate carcinomas [see comments]. Cancer Invest 11: 25-32, 1993
132. Pechl ГJM, Wehner N, Stamey T $\triangle$ : $\Lambda$ ctivaled Ki-ras oncogene in human prostatic adenocarcinoma. Prostate $10: 281$ 289, 1987

133. Tsujii T, Yonese J, Kojima S, Tari K, Ishii M, Seino Y' [Th clinical uscfulness of urinary basic fetoprotein (BFP) in palients with urological malignancies]. [Japanese]. Nippon Hinyokika Gakkai Zasshi 81: 829-834, 1990

134. Gumerlock PH, Poonamallee UR, Mcycrs FJ, De Vere White RW: Activated ras alleles in human carcinoma of the prostate are rare. Cancer Res 51: 1632-1637, 1991

135. Konishi N, Enomoto ' $\mathrm{T}$, Bu/ard (j, Ohshinid . M, Ward JM, Rice JM: K-ras activation and ras p21 expression in latent prostatic carcinoma in Japanese men. Cancer 69: 22932209,1992

136. Anwar K, Nakakuki K, Shiraishi T, Naiki H, Yatani R. Inuzuka $\mathrm{M}$ : Presence of ras oncogene mutations and human papillomavirus DNA in human prostate carcinomas. Cancer Res 52: 5991-5996, 1992

137. Moul, Theune SM, Chang FH: Detection of ras mutations in archival testicular germ cell tumours by polymerase chain reaction and oligonuclcotide hybridization. Genes Chromosom Cancer 5: 109-118, 1992

138. Vocller HJ. Wilding G, Gelmann EP; v-rasH expression confers hormone-independent in vitro growth to LNCaP prostate carcinoma cells. Mol Endocrinol 5: 209-216, 1991

139. Treiger B, Isaacs J: Expression of a transfected v-Harveyras oncogene in a Dunning ral prostate adenocarcinoma and the development ol high metastatic ability. J Urol 140 : 1580-1586, 1988

140. Schalken JA, Ebeling SB, Isaacs JT, Treiger B, Bussemakers; MJ, de Jon ME, Van de Ven WJJ: Down modulation of fibronectin messenger RNA in metastasizing rat prostatic cancer cells revealed by differential hybridization analysis. Cancer Res 48: 2042-2046, 1988

141. Partin AW, Isaacs JT, Ireiger B, Colley DS: Early cell motility changes associated with an increase in metastatic ability in rat prostatic cancer cells transfected with the v-Harvey-ras oncogene. Cancer Res 48: 6050-6053, 1988

142. Carter BS, Epstein JI, Isaacs WB: Ras gene mutations in human prostate cancer. Cancer Res 50: 6830-6832, 1990

143. Viola MV, Fromowity F, Oravez S, Deb S, Finkel G. Lundy J, Hand P. Thor A, Schlom J: Expression of ras oncogene p21 in prostate cancer, $N$ Engl $J$ Med 314: 133-137, 1986

144. Sumiya H, Masai M, Akimoto S, Yatani R, Shimazaki J: Histochemical examination of expression of ras p21 protein and $\mathrm{R}$ 1881-binding protein in human prostatic cancers. Eur J Cancer 26: 786-789, 1990

145. Van ${ }^{\prime} A$, Austin GE, $\mathrm{O}^{\prime}$ Conncll AC: Antibodics to ras oncogene $\mathrm{p} 21$ proteins lack immunohistochemical specificity for neoplastic epithelium in human prostate tissuc. Arch Pathol Lab Med 113: 16-19. 1989

146. Bussemakers MJ, Isaacs JT, Debruyne FMJ, Van der Ven WJM, Schalken JA: Oncogene expression in prostate cancer. World J Lrol 9: 58-63, 1991

147. Cooke DB, Quarmby VE, Petrusz P, Mickey DD, Der CJ, Isaacs JT, French FS: Expression of ras proto-oncogenes in 
the Dumning R3327 rat prostatic adenocarcinoma system. Prostate 13: 273-287, 1988

148. Kato GJ, Barret J, Villa Garcia M, Dang C: An amino terminal c-mye domain required for ncoplastic transformation activates transcription. Mol Cell Biol 10: 5914-5920, 1990

149. Escort C, lhcillet C, Lidereau R, Spyratos F, Champeme $\mathrm{MH}$, Gest M, Callahan R: Genetic alterations of the c-myc proto-oncogene in human primary breast carcinoma. Proc Natl Acad Sci USA 83: 4834, 1986

150. Fleming WH, Hamcl A, MacDonald $\mathbf{R}$, Ranisey $\mathbf{E}$, Petligrew NM, Johnston B, Dodd JG, Matusik RJ: Expression of the c-myc protooncogene in human prostatic carcinoma and benign prostatic hyperplasia. Cancer Res 16: 15351538,1986

151. Phillips ME. Ferro MA, Smith PJ, Davies P: Intranuclear androgen receptor deployment and protooncogene expression in human diseased prostate. Urol Int 42: 115-119, 1987

152. Buttyan R, Sawczuk IS, Benson MC, Siegal JD, Olsson CA: Enhanced expression of the c-myc protooncogene in highgrade human prostate cancers. Prostate 11: 327-337. 1987

153. Cooke DB, Quarmby VE, Mickey DD. Isaacs JT, French FS: Onengerne expression in prosiale cancer. Dumning R3327 rat dorsal prostatic adenocarcinoma system. Prostate 13: 263-272, 1988

154. Eaton CL. Davies P, Phillips ME: Growth factor involvement and oncogene expression in prostatic tumours. J Steroid Biochem 30: 341-345, 1988

155. Matusik RJ, Fleming WH, Hamel A, Westenbrink IG, I Irabarchuk B, MacDonald R, Ramsey R, Gartner JG, Pcttigrcw NM, Johnston B el al.: Expression ol the c-myc proto-oncogene in prostatic tissuc. [Revicw]. Prog Clin Biol Res 239: 91-112.1987

156. Funa K, Nordgren H, Nilsson S: In situ expression of mRNA for proto-oncogenes in benign prostatic hyperplasia and in prostatic carcinoma. Scand J Lirol Nephrol 25: $95 \cdots 100,1991$

157. Thompson TC, Southgate J, Kitchener (y, Land H: Multistage carcinogenesis induced by ras and myc oncogenes in a reconstituted organ. Cell 56:917 930,1989

158. Carter IIB, Piantadosi S, Isaacs JT: Clinical evidence for an implications of the multistep development of prostate cancer. J Urol 143: 742--746, 1990

159. Hynes NE, Gerber HA, Saurer S, Groner B: Overexpression of the c-erbB-2 protein in human breast tumor cell lines. J Cell Biochem 39: 167-173, 1989

160. King CR, Kraus $\mathrm{MH}$, Aaronson SA: Amplification of a novel $v$-crbB-related gene in a human mammary carcinoma. Science 229: 974-976.1985

161. Slamon DJ, Clark GM, Wong SG, I evin WJ, Ullrich A, McGuire WL: I Iuman breast cancer: correlation of relapse and survival with amplification of the HER-2/neu oncogene. Science 235: 177-182, 1987

162. Slamon DJ, Godolphin W, Jones I A, Holt JA, Wong SG, Keith DE, Levin WJ, Stuart SG, Udove J, Ulirich A et al.:
Studies of the HER-2/ncu proto-oncogene in human breast and ovarian cancer. Science 244: 707-712, 1989

163. Zhau IIE, Wan DS, Zhou J, Miller GJ, von Eschenbach AC: Expression of c-crb B-2/ncu proto-oncogene in human prostatic cancer tissues and cell lines. Mol Carcinog 5: $320-327,1992$

164. Ware JL. Maygarden SJ, Koontz WW Jr, Strom SC: Immunohistochenmical detection of c-crbB-2 protcin in human benign and neoplastic prostate. Hum Pathol 22: 254-258, 1991

165. Mellon K, Thompson S, Charlton RG, Marsh C, Robinson M, Lane DP, Harris AL, Home CH, Neal DE; p53, cerbB-2 and the cpidermal growth factor receptor in the benign and malignant prostate. J Urol 117: 196 199, 1992

166. Visakorpi T, Kallionicmi OP, Koivula T, Iarvey I, Isola I: Expression of epidermal growth factor receptor and ERBB2 (HER-2/Neu) oncoprotein in prostatic carcinomas. Mod Pathol 5: 643-648, 1992

167. Sadasivan R, Morgan R, Jennings S, Austenfeld M, Van Veldhuizen P. Stephens R, Noble M: Overexpression of I Ier-2/neu may be an indicalor of poor prognosis in prostate cancer. J Urol 150: 126-131, 1993

168. Kuhn EJ, Kurnot RA, Sesterhenn IA, Chang EH, Moul JW: Fxpression of the c-erbR-2 (HFR-2/neu) ancoprotein in human prostatic carcinoma. [Review]. J Urol 150; 1427 . 1433,1993

169. Klotz I.H, Auger M, Andrulis I, Srigley J: Molecular analysis of neu, sis, c-myc, fos, and P53 oncogenes in benign prostatic hypertrophy and prostatic carcinoma. J Urol 143: $401 \mathrm{~A}, 1990$

170. Grob MB, Solnellhammer Pl; Wright GL et al.: Lixpression of the c-erbB2 oncogene in human prostatic carcinoma. J Urol 145: 294A, 1991

171. Smith RG. Nag AL: Regulation of c-sis expression in tumors of the male reproductive tract. [Review]. Prog Clin Biol Res 239: 113-122, 1987

172. Rijnders AW, Van der Korput JA, Van Steenbrugge (J.J, Romijn JC, lrapman J: Expression of cellular oncogenes in human prostatic carcinoma cell lines Biochem Biophys Res Commun 132: 548-554, 1985

173. Davies $P$, Eaton CL, Franee TD, Phillips ME: Growth fac tor receptors and oncogene expression in prostate colls. [Review]. Am J Clin Oncol 11 Suppl 2: S1-7, 1988

174. McIonnell TJ, Troncoso P, Brisbay SM. I logothetis CJ, Chung LK, Hsieh JT: Bel-2 expression in androgen-independent prostate carcinoma. J Lrol 149: 221A. 1993

175. Raffo $\Lambda J$, Perlman H, Chen MW, Day MI, Streitman JS, Buttyan R: Overexpression of bcl-2 protects prostate cancer cells lrom apoptosis in vitro and confers resistance to androgen depletion in vivo. Cancer Res 55: 4438-4445, 1095

176. Fearon F.R, Vogelstein BA: $\Lambda$ genetic model for colorectal tumorigenesis. (ell 61: 759-769, 1990)

177. Semayer'1A, Cavenec WK: Biology of disease: molecular mechanisms of oncogenesis. I ab Invest $60: 585-599$, 1989 
178. Marshall C: Tumor suppressor genes. Cell 64: 313-326, 1991

179. Weinberg RA: Tumor suppressor genes. Science 254:249270,1991

180. Romas NA, Kwan DJ: Prostatic acid phosphatase. Bionolecular features and assays for serum determination. [Reviewl. Urol Clin North Am 20: 581-588, 1993

181. Nigro JM, Baker SJ, Preisinger AC, Jessup JM. Hostetter R, Cleary K, Bigner SH, Davidson N, Baylin S, Devilee Pet al.: Mutations in the p 53 gene occur in diverse human tumour types. Nature 342: 705 708, 1489

182. Hollstein M, Sidransky D, Vogelstein B, Harris CC: p53 mutations in human cancers. [Review]. Science 253:49-53, 1901

183. Malkin D, Li FP, Strong LC, Fraumeni J Jr, Nelson CE, Kim DII, Kassel J, Gryka MA, Bischofl FZ, Tainsky MA, Friend $\mathrm{SH}$ : Germ line 53 mutations in a familial syndrome of breast cancer, sarcomas and other neoplasms. Science 250: $1233 \cdots 1238,1990$

184. Frebourg I, friend SH: Cancer risks from germ-line p53 mutations. J Clin Invest 90: 1637-1641, 1992

185. Friend SH, Horowily JM, Gerber MR, Wang XF, Bogenmann E, Li F.P, Weinberg RA: Deletions of a DNA sequence in retinoblastomas and mesenchymal 1 umors organization of the sequence and its encoded protein [published crratum appears in Proc Natl Acad Sci USA 1988 Apr; 85 (7): 2234]. Proc Natl Acad Sci USA 84: 9059-9063, 1987

186. Mendoza AE, Shew JY, I ee EY, Bookstein R. Lee WH: $\wedge$ case of synovial sarcoma with abnormal expression of the human retinoblastoma susceptibility gene. I lum Pathol 19: 487-489. 1983

187. Harbour JW, L ai SL, Whang-Peng J, Gazdar AF, Minna JD, Kaye FJ: Abnormalities in structure and expression of the human retinoblastoma gene in SCLC. Science 241: 353-357, 1988

188. 'I'Ang A, Varley IM, Chakraborty S, Murphree AL, Fung YK: Structural rearrangement of the retinoblastoma gene in human breast carcinoma., Science 242: 263-266, 1988

189. Yokota J, Akiyama T, Fung YK, Benedict WF, Namba Y, Hanaoka M, Wada M, Terasaki 1, Shimosato Y, Sugimura $T$ et al.: Altered expression of the retinoblastoma (RB) gene in small-cell carcinoma of the lung. Oncogene 3:471475,1988

190. Varley JM, Armour J. Swallow JE, Jetfreys AJ, Ponder BA, T'Ang A, Fung YK, Brammar WJ, Walker RA: The retinoblastoma gene is frequently altered leading to loss of expression in primary breast tumours [published erratum appears in (oncogene 199u Feb: 5 (2): 245]. Oncogene 4: 725729,1989

191. Bookstein R. Shew JY, Chen PL, Scully P, Lee WII: Suppression of tumorigenicity of human prostate carcinoma cclls by replacing a mutated RB gene. Science $247: 712-715$, 1990

192. Bookstein R, Rio P, Madreperla SA, Hong F, Allred C, Grizkle WE, Lee WH: Promoter deletion and loss of reti- noblastoma gene expression in human prostate carcinoma. Proc Natl Acad Sci USA 87: 7762-7766, 1990

193. Brooks JD, Bova GS. Isaacs WB: Allelic loss of the retinoblastoma gene in primary human prostatic adenocarci nomas. Prostate 26: 35-39, 1995

194. Donehower LA, Bradeley A: The tumor suppressor gene p53, Biochim Biophys $\wedge$ cta 1155: 181-205, 1993

195. Levine AJ: The TSGs. Ann Rev Biochem 621: 623-651. 1993

196. Harris CC, Hollstcin M: Clinical implications of the p53 tumor-suppressor gene [see comments]. [Review]. N Eng] J Med 329: 1318-1327, 1993

197. Takahashi T, Suzuki H, Hida T, Sckido Y, Ariyoshi Y, Leda R: The p53 gene is very frequently mulated in small-cell lung cancer with a distinct nucleotide substitution paltern. Oncogene 6: 1775-1778, 1991

198. Sidransky D, von Fschenbach A, Tsai YC, Jones P, Summerhayes I, Marshall F, Paul M, Green P, Hamilion SR, Frost $P$ et al.: Identification of p53 gene mutations in bladder cancers and urine samples. Science 252: 706-709, 1991

199. Visakorpi T, Kallionienii OP. Hickikinen A, Kuivula ' l, Isola $\mathrm{J}$ : Small subgroup of aggressive, highly proliferative prostatic carcinomas defined by p53 accumulation. J Natl Cancer Inst 84: 883-887, 1992

200. Bookstcin R, Mac(Jrogan D, Hilsenbeck SG. Sharkey F, Allred DC: 053 is mutated in a subset of advanced-stage prostate cancers. Cancer Res 53: 3369-3373, 1993

201. Dinjens WN, Van der Weiden MM. Schroeder FH, Bosman $\mathrm{FT}$, Trapman J: Frequency and characterization of p53 muLations in primary and metastatic human prostate cancer. Int J Cancer 56: 630-633, 1994

202. Voeller HJ, Sugars LY, Prellow T, Gelmann EP: p53 oncogene mutations in human prostate cancer specimens. J Urol 151: 492-495, 1994

203. Navone NM. Troncoso P, Pisters LL, Goodrow TI., Palmer JI, Nichols WW, von Eschenbach AC. Conti CJ: p53 protein accumulation and gene mutation in the progression of human prostate carcinoma. J NatI Cancer Ins1 85: 16571669,1993

204. Effert PJ, McCoy RH, Walther PJ, Liu ET: p53 gene alterations in human prostate carcinoma. J Urol 150: 257-261, 1993

205. Aprikian AG, Sarkis $\Lambda$ S, Fair WR, Zhang $/ F$, Fuks Z, Cordon-Cardo C: Immunohistochemical determination of p53 protein nuclear accumulation in prostatic adenocarcinoma. J Urol 151: 1276-1280, 1994

206. Evans RM: The steroid and thyroid homone receptor superfamily. Science 240: 889-895, 1988

207. Brinkmann AO, Kuiper GG, Ris-Stalpers C, Van Rooij IIC, Romalo G, Triliro M, Mulder F, Pinsky L. Schweikert HL!, Trapman I. Andrngen receptor abnormalities. [Revicw]. J Steroid Biochem Mol Biol 40: 349-352, 1991

208. Faber PW, Van Rooij HCJ, Schipper HP, Brinkmann AO, Trapman J: 'Two different, overlapping pathways of transcription initiation are active on the TAT-less human an- 
drogen receptor promoter. J B1ol Chem 268: Y296-9301, 1993

209. Rundlett SE, Wu XP, Miesleld RL: Functional characterizations of the androgen receptor confirm that the molecular basis of androgen action is transcriptional regulation. Mol Endocrinol 4: 708-714, 1990

210. Jenster $G$, Van der Korput HA, Van Vroonhoven C, Van der Kwast TH, Trapman J, Brinkmann AO: Domains of the human androgen receptor involved in steroid binding, transcriptional activation, and subcellular localization. Mol Endocrinol 5: 1396-1404, 1991

211. Luisi BF, Xu WX, Otwinowski Z, Fecdman LP. Yamamoto KR, Sigler PB: Crystallographic analysis of the interaction nf the glucomorticnid receptor with IONA Nalure 352: 497_ 505,1991

212. Picard D, Kumar V, Chambon P, Yamamoto KR: Signal transduction by steroid hormones: nuclear localization is differentially regulated in estrogen and glucocorticoid receptors. Cell Regul 1: 291-299, 1990

213. Tilley WD, Wilson CM, Marcelli M, McPhaul MJ: Androgen receptor gene expression in human prostate carcinoma cell lines. Cancer Res 50: 5382-5386, 1990

214. Visakorpi 'T, Hyytinen E, Koivisto P. Tanner M, Keinanen R. Palmberg C. Palotie A. Tammela I. Isola J. Kallioniemi OP: In vivo amplification of the androgen receptor gene and progression of human prostate cancer. Nat Genet 9: $401-406,1995$

215. Klocker H, Culig Z, Kaspar F, Hobisch A, Eberle J, Reissigl A. Bartsch $\mathrm{G}$ : Androgen signal transduction and prostatic carcinoma. [Review]. World J Lrol 12: 99-103, 1994

216. Barrack ER, Bujnovsky P, Walsh PC: Subcellular distribu tion of androgen receptors in benign hyperplastic and malignant prostatic tissues: charactcrisation of salt resistant receptors. Cancer Res 43: 1107-1116, 1983

217. Kyprianou X, Davies P: Association stales of androgen receptor nuclei of human benign hypertrophic prostate. Prostate 8: 363-380, 1986

218. Ekman P, Brolin J: Steroid receptor profile in human prostate cancer metastases as compared with primary prostatic carcinoma. Prostate 18: 147-153, 1991

219. Masai M, Sumiya H, Akimoto S, Yatani R, Chang CS, Liao SS, Shimazaki J: Immunohistochemical study of androgen receptor in benign hyperplastic and cancerous human prostates. Prostate 17: 293-300, 1990

220. Suzuki II, Sato N, Watabe Y, Masai M, Seino S. Shimazaki $\mathrm{J}$ : Androgen receptor gene mutations in human prostate cancer. J Steroid Biochem Mol Biol 46: 759-765, 1993

221. Newnar k JR, I Iardy DO, Tonb DC, Carter BS, Epstein JI, Isaacs WB, Brown TR, Barrack ER: Androgen receptor gene mutations in human prostate cancer. Proc Natl Acad Sci USA 89: 6319-6323, 1992

222. Gaddipati JP, McLeod DG, Heidenberg HB, Sesterhenn IA, Finger MJ, Moul JW, Srivastava S: Frequent detection of codon 877 mutation in the androgen receptor gene in advanced prostate cancers. Cancer Res 54: 2861-2864, 1994

223. Edwards A, I Iammond HA, Jin L, Caskey CT, Chakrabor- ty R: (ienetic variation of tive trimeric and tetrameric tandem repeal loci in four human population groups. Crenomics 12: 241-253, 1992

22/. Sleddens HF, Oostra BA, Brinkmann AO et al.: Tyrinucleotide $(\mathrm{GGN})$ repeat polymorphism in the human androgen receptor. Hum Mol Genet 2: 273, 1993

225. Chamberlin NL, Driver ED, Mieslield RL: The length and location of CAG trinucleotide repcats in the androgen receptor $\mathrm{N}$-terminal domain effect transactivation function. Nucleic Acids Res 22: 3181-3186, 1994

226. Irvine RA, Yu MC, Ross RK, Coelzee (jA: The CAG and GGC microsatellites of the androgen receptor gene are in linkage disequilibrium in men with prostate cancer. Cancer Res 55.1937-1940,1095

227. Schoenberg MP, Hakimi JM, Wang S, Bova GS, Epstein Jl, Fischbeck KH, Isaacs WB, Walsh PC, Barrack ER: Microsatellite mutation (CAG24 $\rightarrow 18$ ) in the androgen receptor gene in human prostate cancer. Biochem Biophys Res Commun 198: 74-80.1994

228. Byrne RL, Leung $H$, Neal DE: Peptide growth factors in the prostate as mediators of stromal cpithclial interactions Br J Urol 77: 627-633, 1996

229. Norgaard P, Hougaard S, Poulsen HS, Spang-Thomsen M: Transforming growth lactor beta and cancer. [Review]. Cancer Treat Rev 21: 367-403, 1995

230. Kim IY, Ahn HJ, Zclner DJ, Shaw JW, Sensibar JA, Kim $J H$, Kato M. Lee C: Genetic change in transforming growth factor beta (TGF-beta) receptor type I gene correlates with insensitivity to TGF-beta 1 in human prostate cancer cells. Cancer Res 56: 44-48, 1996

231. Coldstein D, O'Leary M, Mitchen J, Borden EC, Wilding $\mathrm{G}$ : Effects of interferon beta ser and transforming growth lactor beta on prostatic cell ines. J Urol 146: 1173-1177, 1991

232. Zentella A, Weis FM, Ralph DA, Laiho M, Massague J: Farly gene responses to transforming growth factor-beta in cells lacking growth-suppressive RB lunction. Mol Cell Biol 11: 4952-4958, 1991

233. Iruong LU, Kadmon $\mathrm{D}$, McCune BK, Flanders KC, Scardino PT, Thompson TC: $\Lambda$ ssociation of transforming growth factor-beta 1 with prostate cancer: an immunohistochemical study. Hum Pathol 24: 4-9, 1093

234. Ivanovic V, Mclman A. Davis-Joscph B, Valcic M, Gclicbter J: Elevated plasma levels of TGF-beta 1 in patients with invasive prostate cancer [letter]. Nature Med 1: 282-284, 1995

235. Morton DM, Barrack ER: Modulation of transforming growth factor beta $1 \mathrm{cffects}$ on prostatc cancer cell proliferation by growth factors and extracellular miatrix. Cancer Res 55: 2596-2602, 1995

236. Stciner MS, Barrack ER: 'Iransforming growth factor-beta 1 overproduction in prostate cancer: effects on growth in vivo and in vitro. Mol Endocrinol 6: 15-25, 1992

237. Wilding G, Zugmeier G, Knabbe C, Flanders K, Gelmann E: Differential elfects of transforming growth factor beta on human prostate cancer cells in vitro. Mol Cell Endocrinol 62: 79-87, 1989 
238. Desruisseau, Ghasarossian Ragni E, Chinot O, Martin PM: Divergent effect of l'GFbetal on growth and proteolytic modulation of human prostatic cancer cell lines. Intern J Cancer 66: 796-801, 1996

239. Cooney KA, Welzel JC. Merajver SD, Macoska JA, Singleton TP. Wojno KJ: Distinct regions of allelic loss on $13 \mathrm{q}$ in prostate cancer. Cancer Res 56: 1142-1145, 1996

240. Lloyd SN, Brown LL, Leake RF: Transforming growth factor-alpha expression in benign and malignant human prostatic discaso Int J Riol Markers 7: 27-34, 1992

241. Ching K7. Ramsey E, Pettigrew N, D'Cunha R, Jason M, Dodd JG: Fxpression of mR.YA for epidermal growth factor, translorming growth factor-alpha and their receptor in human prostate tissue and cell lines. Mol Cell Biochem 126: $151-158,1993$

242. Morris GL, Dodd JG: Epidermal growth factor receptor mRNA levels in hunan pustatic tumors and cell lines. J Urol 143: 1272-1274, 1990

243. Fox SB, Persad RA, Coleman N, Day CA. Silcocks PB, Collins $\mathrm{CC}$ : Prognostic value of $\mathrm{c}$-crbB-2 and epidermal growth factor reccptor in stage A1 (Tla) prostatic adenocarcinona. Br J Urol 74: 214-220, 1994

244. Connolly JM, Rose DP: Sccretion of epidermal growth factor and related polypeptides by the DU 145 human prostate cancer cell linc. Prostate 15: 177-186, 1989)

245. Connolly JM, Rose DP: Autocrine regulation of DU145 human prostate eancer cell growth by cpidermal growth factor-related polypeptides. Prostate 19: 173 180, 1991

246. Hofer DR, Sherwood ER, Bromberg WD, Mendelsohn J, Lee C, Kozlowski JM: Autonomous growth of androgenindependent buman prostatic carcinoma cells: role of transforming growth factor alpha. Cancer Res 51: 27802785.1991

247. Connolly JM. Kose DP: Production of epidermal growth factor and transforming growth lactor-alpha by the androgen-responsive LNCaP human prostate cancer cell line. Prostate 16: 209-218, 1090

248. Liu XH, Wilcy HS, Meikle AW: Androgens regulate prolifcration of human prostate cancer cells in culture by increasing transforming growth factor-alpha (TGF-alpha) and epidermal growth factor (EGF)/ TGF-alpha receptor. J Clin Endocrinol Metatb 77: 1472-1478, 1993

249. Schuurmans AL, Bolt J, Mulder E: Androgens stimulate both growth ratc and epidermal growth factor receptor activity of the human prostate tumor cell LNCaP. Prostate 12: 55-63, 1988

250. Brass AI, Barnard . Patai RT., Salvi D, Rukstalis DR: Androgen up-regulates epidermal growth factor receptor expression and binding affinity in PC3 cell lines expressing the human androgen receptor. Cancer Res 55: 3197-3203, 1905

251. Xie H, Turner 'l, Wang MH, Singh RK, Siegal GP, Wells A: In vitro invasiveness ol DU-145 human prostate carcinoma colls is modelated by LGI" receptur-nledialed signals. Clin Fxp Mctastasis 13: 407-419, 1995
252. Liu DF, Rabbani SA: Induction of utinary plasininugun aclivator by retinoic acid results in increased invasiveness of human prostate cancer cells PC-3. Prostate 27: 269-276. 1995

253. Jarrard DF, Blitz BF, Smith RC, Patai BL, Rukstalis DB: Effect of epidernal growth factor on prostate cancer cell line PC.3 growth and invasion. Prostate 24: 46-53, 1994

254. Pinskı J, Reile H, Halmos (i, Groot K, Schally AV: Inhibitory cffects of somatostatin analogue RC- 160 and bombesin/gastrin-releasing peptide antagonist RC-3095 on the growth of the androgen independent Dunning R-3327AI-1 rat prostate cancer. Cancer Res 54: 169-174, 1994

255. Pinski J, Reile I, Halmos G, Groot K, Schally AV: Inhibitory effects of analogs of utcinizing hormonc-releasing hormone on the growth of the androgen-independent Dunning R-3327-AT-1 rat prostate cancer. Int J Cancer 59: $51-55,1994$

256. Kim JH I, Sherwood FR. Sulkowski DM. Lee C, Kozlowsk। JM: Inhibition of prostatic tumor ccll proliferation by suramin: alterations in $\mathrm{IGF}$ alpha-mediated autocrine growth regulation and cell cycle distribution. J Crol 146: 171 176, 1991

257. Cohen P, Pechl DM, Rosenfeld RG: The IGF axis in the prostate. [Revicw]. Horm Metab Res 26: 81-84, 1994

258. Kaicer EK, Blat C, Harel L: IGF-I and IGiF-binding proteins: stimulatory and inhibitory lactors secreted by human prostatic adenocarcinoma cells. Growth Factors 4: 231237,1991

259. Iwamura M, Sluss PM, Casamento JB, Cockett AT: Insulin-like growth factor I: action and receptor characterization in human prostatc cancer cell lines. Prostate 2.: 24.3252. 1993

260. Pietr\%kowski Z, Mudholland G, Gomclla L, Jameson BA, Wernicke D, Baserga R: Inhibition of growth of prostatic cancer cell lines by peptide analogues of insulin-like growth factor 1. Cancer Res 53: 1102-1106, 1993

261. Polychronakos C, Janthly U, Lehoux JF, Koutsilieris M: Mitogenie elfects of insulin and insulin-like growth factors on PA-III rat prostate adenocarcinoma cells:characterization of the receptors involved. Prostate 19: 313-321. 1991

262. Culig Z, Hobich A. Cronauer MV, Radmayr C, Trapman J. Hittmair A, Bartsch G, Klocker II: Androgen receptor activation in prostatic tumor cell lines by insulin-like growth factor-I, keratinocytc growth factor, and cpidermal growth factor. Cancer Kes $54: 54 / 4-54 / 8,1994$

263. Koulsilieris M, Polychronakos $\mathrm{C}$ : Protcinolytic activity against IC $\mathrm{jF}$-binding proteins involved in the paracrine interactions between prostate adenocarcinoma cells and os teoblasts. Anticancer Res 12: 905-910, 1992

264. Janssen T, Kiss R, Dedccker R, Petein M, Pasteels JL, Schulman C: Infuence of dihydrotestosterone, epidermal growth factor, and basic fibroblast growth factor on the cell kinetics of the PC3, DU145, and LNCaP prostatic cancer cell lines: relationship with DNA ploidy level. Prostate 27: 277.286, 1995

265. Gleave ME. Hsich JT, von Eschenbach $\triangle \mathrm{C}$. Chung LW: 
Prostate and bone fibroblasts induce human prostate cancer growth in vivo: implications for bidirectional tumorstromal cell intcraction in prostate carcinoma growth and metostasiti. J Urol 117: 1151 1159, 1992

266. Nelson JB, Hedican SP, George DJ, Reddi AH, Piantadosi S, Eiscnberger MA. Simons JW: Identification of endothelin-1 in the pathophysiology of melastatic adenocarcinoma of the prostate. Nature Med 1: 944-949, 1995

267. Nelson JB, Chan-Tack K, Hedican SP, Magnuson SR, Opgenorth TH, Bova GS, Simons JW: Endothelin-1 production and decreased endothin $B$ receptor cxpression in advanced prostate cancer. Cancer Res 56: 663-668, 1996

268. Kobayashi S, Tang R, Wang B, Opgenorth I, Stein E, Shapiro E, I.epor $\mathrm{H}$ : L.ocalization of endothelin receptors in the human prostate. I Urol 151: 763-766, 1994

269. Warner ID, de Nucci G, Vane JR: Rat endothclin is a vasodilator in the isolated perlused mesentery of the rat. Eur $J$ Pharmacol 159: 325-326, 1989

270. Hirata Y, Emori T, Eguchi S, Kanno K, Imai T, Ohta K, Marumo F: Endothelin receptor subtype B mediates the synthesis of nitric oxide by bovine endothelial cells. J Clin Invest 91: 1367 -1373, 1993

271. Kitasjima I, Kawahara K, Nakajima T, Sockima Y, Matsuyama T, Marnyama I: Nitric oxide-mediated apoptosis in mastocytoma. Biochem Biophys Res Commun 203: 244 251,1994

272. Xie K, Huang S, Dong Z, Juang SH, Gutman M, Xie QW, Nathan C, Fidler IJ: Transfection with the inducible nitric oxide synthase gene suppresses the tumorigenicity and abrogates metastasis by K-1735 murine melanoma cells. J Lxp Med 181: 1333-1343, 1995

273. Goligorsky MS, Tsukahara H, Magazine II, Anderson TT, Malik AB, Bahou WF: Termination of endothelin signalling: role of nitric oxide. J Cell Physiol 158: 485-494, 1994

274. Boulanger C, Luscher TF: Release of endothelin from the porcine aorta: inhibition by cndothelin-derived nitric oxide. J Clin lnvest 85; 587-590, 199()

275. Graham CW, I ynch JH, Djakiew L: Distributron of nerve growth lactor-like protein and ncrve growth factor receptor in human benign prostatic hyperplasia and prostatic adenocarcinoma. J Urol 147: 1141 1117, 1992

276. Djakiew D, Pflug B, Onoda M: Stromal-epithelial paracrine interactions in the neoplastic rat and human prostate. Adv Exp Med Biol 330; 185-202, 1993

277. Djakiew D, Delsite R. Pflug B, Wrathall J. Lynch JH. Onoda M: Regulation of growth by a nerve growth factor-like protein which modulates paracrine interactions between a neoplastic cpithelial cell line and stromal cells of the human prostate. Cancer Res 51: 3304-3310, 1991

278. Djakiew D, Pflug BR, Delsite R, Onoda M, Lynch JH, Arand $G$, Thompson EW: Chemotaxis and chemokinesis of human prostate tumor cell lines in response to human prostate stromal cell secretory proteins containing a nerve growth factor-like protein. Cancer Res 53: 1416-1420, 1993

279. Yang G, Wheeler TM, Kattan MW, Scardino PT, Thompson TC: Perincural invasion of prostate carcinoma cells is associated with reduced apoptotic index. Cancer 78: 12671271,1996

280. Horigome $\mathrm{K}$, Bullock ED, Johnson EM Jr: Eflects of nerve growth factor on rat peritoneal mast cells. Survival promo tion and immediate-early gene induction. J Biol Chem 269: 2695 2702, 1994

281. Smith RC, I.itwin MS, Lu Y, Zetter BR: Identification of an endogenous inhibitor of prostatic carcinoma cell growth. Nature Med 1: 1040-1044. 1996

282. Cipolla BG, Ziade J, Bansard JY, Moulinoux JP, Stacrman F, Quemener V, Lobel B, Guille F: Pretherapeutic erythrocyte polyamine spcrmine levels discriminatc high risk relapsing patients with $\mathrm{Ml}$ prostate carcinoma. Cancer 78 : 1055-1065, 1996

283. Costello LC, Franklin RB: Elfect of prolactin on the prostatc. [Review]. Prostate 24: 162-166, 1994

284. Janssen T, Darro F, Petcin M, Raviv G, Pasteels JL, Kiss R, Schulman $\mathrm{CC}$ : In vitro characterization of prolactin-induced elfects on proliferation in the neoplastic LNCaP, DU145 and PC3 models of the human prostate. Cancer 77 : $144-149,1996$

285. Rana A, Habib FK, Halliday P, Ross M, Wild R, Elton RA, Chisholm GD: A case for synchronous reduction of testicular androgen, adrenal androgen and prolactin for the treatment of advanced carcinoma ol the prostate [sec comments]. Eur J Cancer 31A: 871-875, 1995

286. Heino J: Biology ol tumor cell invasion: interplay of cell adhesion and matrix degradation. Int J Cancer 65: 717-722, 1996

287. Jewell K, Kapron-Bras C, Jeevaratnam P, Dedhar S: Stimulation of tyrosine phosphorylation of distinet proteins in response to antibody-mediated ligation and clustering of alpha 3 and alpha 6 integrins. J Cell Sci 108: 1165-1174, 1995

288. Knox JD, Cress AE, Clark V, Manriquez I, Alfinito KS, Dalkin BL, Nagle RB: Differential expression of extracellular matrix molecules and the alpha 6-integrins in the normal and neoplastic prostate. Am J Pathol 145: 167--174, 1994

289. Nagle RB, Knox JI, Wolt C; Bowden G 7 ; Cress AE: Adhesion molecules, extraccllular matrix, and proteases in prostate carcinoma. J Cell Biochem Suppl 19: 232-237, 1091

290. Cress $\triangle E$, Rabinovit\% I, Zhu W, Nagle RB: The alpha 6 beta 1 and alpha 6 beta 4 integrins in human prostate cancer progression. Cancer Metastasis Rev 14: 219-228. 1995

291. Cress $\wedge \mathrm{E}$, Rabinovitz I, Zhu W, Nagle RB: The alpha 6 beta 1 and alpha 6 beta 4 integrins in human prostate cancer progression. [Review]. Cancer Metastasis Rev 14: 219-228, 1995

292. Nagle RB, Hao J, Knox JD, Dalkin BI, Clark V, Cress AE: Expression of hemidesmosomal and extracellular matrix protcins by normal and malignant human prostate tissue. Am. J Pathol 146: 1498-1507, 1995

293. Rabinovitz I, Nagle RB, Cress AE: Integrin alpha 6 expression in human prostate carcinoma cells is associated with a migratory and invasive phenotype in vitro and in vivo. Clin Exp Metastasis 13: 481 -491, 1995 
294. Dedhar S, Saulnier R. Nagle R, Overall CM: Specilic alterations in the expression of alpha 3 bela 1 and alpha 6 beta 4 integrins in highly invasive and metastatic variants of human proslate carcinoma cells selected by in vitro invasion through reconstituted basement membrane. Clin Exp Metastasis 11: 391-400, 1993

295. Coppolino M, Migliorini M, Argraves WS, Dedhar S: Identification of a novel form of the alpha 3 integrin subunit: covalent association with transferrin receptor. Biochem J 306: 129.134, 1995

290. Russi MC, Zetter BR. Sclective stimulation of prostatic carcinoma cell proliferation by transferrin. Proc Natl Acad Sci USA 89: 6197-7201, 1992

297. Sokolol' MH. Tso CL. Kaboo R. Taneja S. Pang S. deKernion JB, Belldegrun AS: In vitro modulation of tumor progression-associated propertics of hormone refractory prostate carcinoma cell lines by cytokines. Cancer 77 : $1862-1872,1996$

298. Witkowski CM, Rabinovitz I, Nagle RB, Affinito KS, Cress $\Lambda E$ : Characterization ol integrin subunits, cellular adhesion and tumorgenicity of four human prostate cell lines. J Cancer Res Clin Oncol 119: 637-644, 1993

299. Paul R, Jarrard DF, Bussemakers MJ, Nguyen SH, Bova GS, Schalken JA, Isaacs WL: Loss of P-cadherin expression in prostate cancer. Eur Urol 30(52). 1996 (Abstract)

300. Isaacs WB, Bova (GS, Morton RA, Busscmakers MJ, Brooks JD, Ewing CM: Genetic alterations in prostate cancer. [Revicw]. Cold Spring Harb Symp Quant Biol 59: 653659,1994

301. Limbas R, Schalken JA, Aalders TW, Carter BS, Karthaus HF, Schaafsma HE, Debruyne FM, Isaacs WB: Expression of the cellular adhesion molecule E-cadherin is reduced or absent in high-grade prostate cancer. Cancer Res 52: 51045109,1992

302. Cheng L, Nagabhushan M, Pretlow' TP, Amini SB, Prellow TG: Expression of E-cadherin in primary and metastatic prostate cancer. Am J Pathol 148: 1375-1380, 1996

303. Russ 1S, Figgc HL, Bui HX. del Rusario AD, Fisher HA, Nazeer T, Jennings IA, Ingle R. Kim DN: F-cadherin expression in prostatic carcinoma biopsics: correlation with tumor grade. DNA content, pathologic stage, and clinical outcome. Mod Pathol 7: 835-841, 1994

304. Griroldi LA, Schalken JA: Decreased expression of the intercellular adhesion molecule E-cadhcrin in prostatc cancer: biological significance and clinical implications. Cancor Melastasis Rov 12: 29-37.1993

305. Umbas R, Isaac WB, Bringuier PP, Schaatsma HF, Karthaus IIF, Oostcrhol (jO, Debruyne F.M, Schalken JA: Dccreased E-cadherin expression is associated with poor prognosis in patients with prostate cancer. Cancer Res 54: 3929-3933, 1994

306. Bussenakers MJ, Van Moorselaar RJ, Giroldi LA, Ichikawa T, Isaacs JT, Takeichi M, Debruyne FM, Schalken JA: Decreased expression of E-cadherin in the progression of rat prostatic cancer. Cancer Res 52: 2916-2922, 1992

307. Giroldi LA, Schalken IA: Decreased expression of the in- tercellular adhesion molecule E-cadherin in prostate cancer: biological significance and clinical implications. [Review]. Cancer Metastasis Rev 12: 29-37, 1993

308. Grafl IR, Herman IG, I apidis RG, Chopra H, Xu R, Jarrard DF, Isaacs WB, Pitha $P M$, Davidson NF, Baylin SB; E-cadherin expression is silenced by DNA hypermethylation in human breast and prostate carcinomas. Cancer Res 55: 5195-5199, 1995

309. Schalken JA, Smit F, Bringuier PP, van Bokhoven A, Debruyne FM, Bussemakers MJ: The role of E-cadherin mutations in bladder and prostate cancer; is 5i-cadherin a classical suppressor gene? J Urol 155: 339A, 1996

310. Fwing CM, Ru N, Morton R $\Lambda$, Robinson JC, Wheclock M.I. Johnson KR, Barrett JC. Isaacs WB: Chromosome 5 suppresses tumorigenicity of $\mathrm{PC} 3$ prostatc cancer cells: correlation with re-expression of alpha-catenin and restoration of E-cadherin function. Cancer Res 55: 4813-4817, 1995

311. Birchmeier W, Behrens J: Cadherin expression in carcinomas: role in the lormation of cell junctions and the prevention of invasiveness. Biochim Biophys, Acta 1109: 1126 , 1994

312. Iulsken J, Birchmeier W, Behrens J: F-cadherin and $\triangle P C$ compete for the intraction with beta catenin and the cytoskeleton. J Ccll Biol 127: 2061-2069, 1994

313. Carruba (, Miceli D, D'Amico D. Farruggio R, Comito L, Montesanti A, Polito L. Castagnetta LA: Sex steroids upregulate E-cadherin expression in hormone-responsive LNCaP human prostate cancer cells. Biochem Biophys Res Commun 212: 624-631, 1995

314. Prall F, Nollau P, Neumaier M, I Iuubeck HD, Drzeniek Z, Helmchen U, Loning T, Wagener C: CD66a (BGP), an adhesion molecule of the carcinoembryonic antigen family, is cxpressed in epithelium, endothclium, and mycloid cells in a wide range of normal human tissues. J Histochem Cylochem 44: 35-41, 1996

315. Hsich JT, I, in SH: Androgen regulation of cell adhesion molccule gene expression in rat prostate during us gan clegeneration. C-CAM belongs to a class of androgen-repressed genes associated with enriched stem/amplifying cell population after prolonged castration. I Biol Chem 269: 3711-3716, 1994

316. Kleincrman DI, Troncoso P, Lin SH, Pisters LI. Sherwood ER, Brooks 'T, von Eschenbach AC. Hsich JT: Consisten1 cxpression of an epithelial cell adhesion molecule (CCAM) during human prostate development and loss of expression in prostate cancer: implication as a tumor suppressor. Cancer Res 55: 1215-1220, 1995

317. Lin SH, Luo W, Earley K, Cheung P, Hixson DC: Structure and function of C-C.AMt: effects of the cytoplasmic domain on cell aggregation. Biochen J 311: 239-245, 1995

318. Hsich J-T, Luo W, Song W. Wang Y, Kleinerman DI, Van NT, L in SH: Tumour suppressive role of an androgen-regulated epithclial cell adhesion molecule (C.CAM) in prostate carcinoma cell revealed by sense and antisense approaches. Cancer Res 55: 190-197, 1995 
319. Klcinerman DI, Zhang WW, Lin SH, Nguyen TV, von Eschenbach AC, Hsieh IT: Application of a tumor suppressor (C-CAM1)-expressing recombinant adenovirus in androgen-independent human prostatc cancer therapy: a pieclinical study. Cancer Res 55: 2831-2836, 1995

320. Wollf JM. Stephenson RN. Chisholm GD, Habib FK: Levels of circulating inlercellular adhesion molccule-1 in patients with metastatic cancer of the prostate and benign prostatic hyperplasia. Eur J Cancer 31A: 339-341, 1995

321. Folkman J: Angiogenesis in cancer, vascular, rheumatoid and other discasc. Nature Mcd 1: 27-31, 1995

322. I okeshwar VB. Lokeshwar BI., Pham HT, Block NL: Assuciation of elevated levels of hyaluronidase, a matrix-degrading enzyme, with prostate cancer progression. Cancer Res 56: 651-657, 1996

323. Folkman J. Hanahan D: Switch to the angiogenic phenotype during tumorigenesis. [Review]. Princess Takamatsu Symp 22: 339-347, 1991

324. Holmgren L, O'Reilly MS, Folkman J: Dormancy of micrometastases: balanced proliferation and apoptosis in the presence of angiogenesis suppression. Nature Med 1: 149153,1995

325. Brown LF, Yco KT, Berse B, Morgentaler A, Dvorak HF, Rosen S: Vascular permeability factor (vascular endothelial growth factor) is strongly expressed in the normal male genital tract and is present in substantial quantities in semen. J Urol 154: 576-579, 1995

326. Moon SY, Yoon JH, Moon WC, Seo KK, Ki YJ: Role of angiogenesis and vascular endothelial growth factor in glandular hyperplasia of rat ventral prostale. I Urol 155 (Suppl): 463A, 1996

327. Bertrand $\mathrm{N}$, Jonca $\mathrm{F}$, Moro F, Soedrello $\mathrm{S}$, Malavaud $\mathrm{B}$, Cussenot O, Rischman P, Sarramon JP, Toulonse IP: In vitro regulation of VEGF expression in epithelial prostatic cclls by testosterone. J Urol 155 (Suppl): 603A, 1996

328. Freeman MR, Schneck FX, Gagnon ML, Corless C, Soker S, Nikncjad K, Peoples GF. Klagsbrun M: Peripheral blood T lymphocytes and lymphocytes infiltrating human cancers express vascular endothelial growth factor: a potential role for 'l' cells in angiogencsis. Cancer Res 55: 41404145,1995

329. Vukanovic J, Isaacs JT: Linomide inhibits angiogenesis, growth, melastasis, and macrophage infiltration within rat prostatic cancers. Cancer Res 55: 1499--1504, 1995

330. Chen C, Parangi $S$, Tolentino MJ, Folkman J: $\Lambda$ strategy to discover circulating angiogenesis inhibitors generated by human tumors. Cancer Res 55: 4230-4233, 1995

331. Vukanovic J, I Iartley-Asp B, Isaacs JT: Inhibition of tumor angiogenesis and the therapcutic ability of linomide against rat prostatic cancors. Prostate 26: 235 246, 1995

332. Vukanovic J, Passaniti A, Hirala T, Traystman RJ, HartleyAsp B, Isaacs JI: Antiangiogenic effects of the quinoline-3carboxamide linomide. Cancer Res 53: 1833-1837, 1993

333. Vukanovic J, Isaacs JT: Human prostatic cancer cells are sensitive to programmed (apoptotic) death induced by the antiangiogenic agent linomide. Cancer Res 55: 3517-3520, 1995

334. Siegal JA, Yu E, Brawer MK: Topography of ncovascularity in human prostate carcinoma. Cancer 75: 2545 2551, 1995

335. I Iall MC, Troncoso P, Pollack A, Zhau HY, Zagars GK, Chung LW, von Eschenbach AC: Significance of tumor angiogenesis in clinically localized prostate carcinoma treated with external beam radiotherapy. Urology 44: 869 875 , 1994

336. Weidner N, Carroll PR, Flax J, Blumenteld W, lolkman J: Tumor angiogenesis correlates with metastasis in invasive prostate carcinoma. Am J Pathol 143: 401-409, 1993

3.37. Brawer MK, Deering RE. Brown M, Preston SD, Bigler SA: Predictors of pathologic stage in prostatic carcinoma. The role of neovascularily. Cancer 73: 678 687,1994

338. Rosen PJ. Mendoza EF, Landaw EM, Mondino B, Graves MC, McBride JH, Turcillo P, DeKernion J, Belldegrun A: Suramin in hormone-refractory metastatic prostate cancer: a drug with limited efficacy. J Clin Oncol 14: 1626-1636, 1996

339. Dawson NA. Cooper MR, Figg WD, Headlee DJ, Thibault A, Bergan RC, Stcinberg SM, Sausville FA, Myers CE, Sartor $O$ : Antitumor aclivity of suramin in hormone-refractory prostate cancer controlling for hydrocortisone treatment and flutamide withdrawal as potentially confounding variables. Cancer 76: 453-462, 1995

340. Firsching A, Nickel P, Mora P, Allolio B: Antiproliferative and angiostatic activity of suramin analogues. Cancer Res 55: 4957-4961, 1995

341. Meyer GE, Y'u E, Siegal JA, Pettcway JC, Blumenstcin BA, Brawer MI : Serum basic fibroblast growth factor in men with and without prostate carcinoma. Cancer 76 : 2304-2311. 1995

342. Mohler JL: Cellular motility and prostatic carcinoma metastases. [Review]. Cancer Metastasis Rev 12: 53-67, 1993

343. Stearns ME, Stcarns M: Autocrine factors, type IV collagenase sccretion and prostatic cancer cell invasion. [Review]. Cancer Melastasis Rev 12: 39-52, 1993

344. Doyle GM, Sharicf Y, Mohler JL: Prediction of metastatic potential by cancer cell motility in the Dunning R 3327 prostatic adenocarcinoma in vivo model. J Urol 147: 514 518,1992

345. Picnta KJ, Murphy BC, Isaacs WB, Isaacs JT, Coffey DS: Effect ol pentosan, a novel cancer chemotherapeutic agent, on prostate cancer cell growth and motility. Prostatc 20: 233-241, 1992

346. Stearns ME, Wang M: Immunoassays of the metalloproleinase (MMP-2) and tissue inhibitor of metalloproteinase (TIMP 1 and 2) levels in noninvasive and metastatic PC-3 clones: effects of taxol. Oncol Res 6: 195-201, 1994

347. Stcarns ME, Wang M, Stearns M: IL-10 blocks collagen IV invasion by 'invasion stimulating factor' activated PC-3 ML cells: upregulation of 'TIMP-1 expression. Oncol Res 7 : $157-163,1995$

348. Lokeshwar BL, Selzer MG, Block NL, Gunja-Smith Z: Se- 
crction of matrix metalloprotcinases anıl tlıeir inluilsiturs (tissue inhibitor of melalloproteinases) by human prostate in explant cultures: reduccd tissue inhibitor of metalloproteinase secretion by malignant tissues. Cancer Res 53: 4493 4498, 1993

349. Powcll WC, Knox JD, Navre M, Grogan TM, Kittelson J, Nagle RB, Bowden GT: Expression of the metalloproteinase matrilysin in DU $J-145$ cells increases their invasive potontial in severe combined immunodeficient mice. Cancer Res 53: 417-422, 1993

350. Pajouh MS, Nagle RB, Breathnach R, Finch JS, Brawcr MK, Bowden GI: Expression of metalloproteinase genes in human prostate cancer. I Cancer Res Clin Oncol 117: $144-150,1991$

351. Knox JD, Wolf C., McDanicl K, Clark V, I oriot M, Bowden GI; Nagle RB: Matrilysin expression in human prostate carcinoma. Mol Cardinog 15:: 57-63, 1996

352. Baker $\Upsilon$, Iickle $S$, Wasan $H$, Docherty A, Isenberg D, Waxman J: Serum metalloproteinases and their inhibitors: markers for malignant potential. $\mathrm{Br} \mathrm{J}$ Cancer 70: 506-512, 1904

353. Hsu DW, Efird JT, Hedley-Whyte ET: Prognostic role of urokinase-type plasminogen activator in human gliomas. Am J Pathol 147: 114-123, 1995

354. Achibarou A, Kaiser S, Tremblay G, Ste-Marie I.G, Brodt P, Goltzman D: Urokinase over-production results in increased skeletal metastasis by prostate cancer in vitro. Caucer Rcs 54: 2373-2377, 1994

355. Keer IN, Gaylis FD, Kozlowski JM, Kwaan HC, Bauer KD. Sinha AA, Wilson MJ: Heterogeneity in plasminogen activator (PA) levels in human prostate cancer cell lines: increased PA activity correlates with biologically aggressive behavior. Prostate 18: 201-214, 1.991

356. IJille B: Ionic Channels of Excitable Membranes. Sunderland, Massachusetts: Sinauer Associates Inc. 1992

357. Cohen-Armon M, Sokolovsky M: Evidence for involvement of the voltage-dependent $\mathrm{Na}+$ channel gating in depolarization-induced activation of G-proteins. J Biol Chem 268: 9824-9838, 1993

358. Woodfork KA, Wonderlin WF, Peterson VA, Strobl JS: Inhibition of ATP-sensitive potassium channels causes reversible cell-cycle arrest of human breast cancer cells in tissue culture. J Cell Physiol 162: 163-171, 1995

359. Wonderlin WF, Woodfork KA, Strobl JS: Changes in membrane potential during the progression of $\mathrm{MCF}-7$ human mammary tumor cells through the cell cycle. J Cell Physiol 165: 177-185, 1995

360. Kondo S, Yin D, Morimura T, Kubo II, Nakatsu S, Takcuchi $\mathrm{J}$ : Combination therapy with cisplatin and nifedipine induces apoptosis in cisplatin-sensitive and cisplatin-resistant human glioblastoma cells. Br J Cancer 71: 282-289, 1995

361. Van Dolah FM. Ramsdell IS: Maitotoxin, a calcium channel activator, inhibits cell cycle progression through the G1/S and $\mathrm{C} 2 / \mathrm{M}$ transitions and prevents CDC2 kinase act1vation in GH4C1 cells. J Cell Physiol 166: 49-56, 1996
362. Nagy P, Panyi G, Jenei A, Bene L, Gaspar R Jr, Matko J, Damjanovich S: Ion-channel activitics regulate transmembrane signaling in thymocyle apoptosis and $\mathrm{T}$-cell activation. Immunol I e1t 44: 91-95, 1905

363. Arcangeli A. Becchetti A, Mannini A, Mugnai G, De Filippi P, Tarone (, , Del Bcne MR. Barletta E, Wanke E, Oljvotto $\mathrm{M}$ : Integrin-mediated neurite outgrowth in neuroblastoma cells depends on the activation of potassium channels. J Cell Biol 122: 1131-1143, 1993

364. Isom LL, Ragsdale DS, De Jongh KS, Westenbrock RE, Reber BF, Scheuer T, Catlerall WA: Structure and function of the beta 2 subunit of brain sodium channels, a transmembrane glycoprotein with a CAM motil. Cell 83: 433442. 1995

365. Becchetti A, Arcangeli A, Del Bene MR, Olivolto M, Wanke E: Response to fibroncctin-integrin interaction in leukaemia cells: delayed enhancing of a K+current. Proc R Soc Lond B Biol Sci 248: 235-240, 1992

366. Watsky MA: Loss ol keratocyte ion channels during wound healing in the rabbit cornca. Invest Ophthalmol Vis Sci 36: 1095 1099, 1995

367. Schwab A, Wojnowski L, Gabriel K, Obcrleithner H: Oscillating activity of a $\mathrm{Ca}(2+)$-sensitive $\mathrm{K}+$ channel. A prerequisite for migration of transformed Madin-Darby canine kidney focus cells. J Clin Invest 93: 1631-1636, 1994

368. Bokvist K, Eliasson L, Ammala C, Renstrom E, Rorsman P: Co-localization of L-type Ca2+ channels and insulincontaining secretory granules and its significance for the initiation of exocylosis in mousc pancreatic B-cells. EMBO J 14: 50-57, 1995

360. Sheng $Z H$, Rettig J, Cook 'T, Catterall WA: Calcium de pendent interaction of $\mathrm{N}$-type calcium channels with the synaptic core complex. Nature 379: 451-454, 1996

370. Pancrazio JJ, Tabbara IA, Kin YI: Voltage-activated K+ conductance and ccll proliferation in small-cell lung cancer. Anticancer Res 13: 1231-1234, 1993

371. Higgins CF: Volume-activated chloride currents associated with the multidrug resistance $\mathbf{P}$-glycoprolein. [Review]. J Physiol (Lond) 482: 31S-36S, 1995

372. Yamashita N, Hamada H, Tsuruo T, Ogata E: Enhancement of voltage-galed $\mathrm{Na}+$ channol corrent associated with multidrug resistance in human leukemia cells. Cancer Res 46: 3736-3741, 1987

373. Neher E: Nobel lecture. Ion channels for communication between and within cells. [Revicw]. Neuron 8: 605-612, 1992

374. Grimes IA, Fraser SP. Stephens GJ, Downing JE, Laniado ME, rostcr CS, Abel FD, Djangu pression of voltage-activated $\mathrm{Na}+$ currents in two prostatic tumour cell lines: contribution to invasiveness in vitro. FEBS Lett 369: 290-294. 1995

375. Laniado ME, Lalani E-N, Fraser SP, Grimes JA, Bhangal G, Djamgoz. MB, Abel PD: Expression and functional analysis of voltage-activated $\mathrm{Na}+$ channels in human prostate cancer cell lines and their contribution to invasion in vitro. Am J Pathol 1997 (in press) 
376. Laniado MF, Lalani E-N. Fraser SP, Djamgoz MB, Abcl $\mathrm{PD}$ : Outward voltage-activated $\mathrm{K}$ ' currents distinguish LNCaP and PC-3 cell lines. Eur U rol 30(52): 434, 1996 (Abstrael)

377. Marino AA, Iliev IG, Schwalke MA, Gonzalez. E, Marler KC, Flanagan CA: Association between cell membrane polential and breast cancer. Tumour Biol 15: 82-89, 1994

378. Wonderlin WF, Woodfork KA, Strobl JS: Changes in membrane potential during the progression of MCF-7 human mammary tumor cells through the cell cyclc. J Cell Physiol 165: $177 \cdot 185,1995$

379. Schwab A, Gabriel K, Finsterwalder F, Folprecht G, Greger R, Kramer A, Oberleithner H: Polarized ion transport during migralion of transformed Madin-Darby canine kidney cells. Pllugers Arch 430: 802-807, 1995

380. Kyprianou N, English HF, isaacs JT: Aclivation of a $\mathrm{Ca}^{-7}-$ $\mathrm{Mg}^{++}$-dependent endonuclease as an early event in castration-induced prostatic cell death. Prostate 13:103-118, 1988

381. Martikainen P. Isaacs JT: Role of calcium in the programmed death of rat prostatic glandular cells. Prostate 17: $175 \cdots 188,1990$

382. Furuya Y, I.undmo P, Short AD. Gill DL, Isaacs JT: The role of calcium, $\mathrm{pH}$, and cell proliferation in the programmed (apoptotic) death of androgen-independent prostatic cancer cells induced by thapsigargin. Cancer Res 54: 6167-6175, 1994

383. Connor J, Sawczuk IS, Benson MC, Tomashefsky P, O'Toolc KM, Olsson CA, Buttyan R: Calcium channel antagonists delay regression of androgen-dependent tissues and suppress genc activity associated with cell death. Prostate 13: 119 130, 1988

384. McDonnell T, von Eschenbach A, Marin M. Fernandez A, Westin P, Shi-:Ming T, Brisbay S, Bick R, Buju L, McConkey $\mathrm{D}$ : Bcl-2 confers resistance to cell death induction by androgen-ablation and chemotherapy in prostate cancer cells, J Lrol 155 (Suppl): 527, 1996

385. Steinsapir J, Socci R, Reinach P: Eflects of androgen on intracellular calcium of LNCaP cells. Biochem Biophys Commun 179: 90-96, 1991

386. Batra S, Popper LD, Hartley-Asp B: Effcct of calcium and calcium antagonists on $45 \mathrm{Ca}$ influx and cellular growth of human prostatic tumor cells. Prostate 19: 299-311, 1991

387. Peppelenbosch MP, Tertoolen LG, De Laat SW, Zivkovic D: Ionic responses to epidermal growth factor in zebrafish cells. Fxp Cell Res 218: 183-188, 1995

388. Misra RP, Bonni $\Lambda$, Miranti $C K$, Rivera VM, Sheng $M$, Greenberg ME: L-lype voltage-sensitive calcium channel aclivation stimulatus gene expression by a serum response factor-dependent pathway. J Biol Chem 26: 25483-25493, 1994

389. Matsunaga H. Nishimoto I, Kojima I, Yamashita N, Kurokawa K, Ogata E: Activation of a calcium-permeable cation channel by insulin-like growth lactor II in BALB/c $3 \mathrm{~T} 3$ cells. Am J Physiol 255: C442-446, 1988
390. Kanzaki M, Shibata H, Morgami H, Kojima I: Expression of calcium-pcrmeable cation channel CD20 accelerates progression through the $\mathrm{G}$ 1 phase in Balb/c $3 T 3$ cells. J Biol Chem 270: 13090 13101, 1095

391. Huang Y, Rane SG: Polassium channel induction by the Ras/Raf signal transduction cascadc. J Biol Chem 269: 31183-31189, 1994

392. Brown MJ, Loew LM: Elcctric field-directed fibroblast locomotion involves cell surface molccular reorganization and is calcium independent. J Cell Biol 127: 117-128, 1994

393. Carter I LB, Partin AW, Coffey DS: Prediction of metastatic potential in an animal model of prostate cancer: llow cytometric quantification of cell surface charge. J Urol 142: $1338-1341,1089$

394. Carter IIB, Coffey DS: Ccll surface charge in predicting melastatic potential of aspirated cells from the Dunning rat prostatic adenocarcinoma model. J Urol 140: 173-175, 1988

395. Ware JL, Paulson DF, Mickey GH, Webb KS: Spontaneous metastasis of cells of the human prostate carcinoma cell line PC-3 in athymic nude micc. J Urol 128: 1064-1067, 1982

390. Slieı wood FR, Beıg LA, Mitcliell NJ, MoNeal JE, Kozlowski JM, Lee C: Differential cytokeratin expression in normal, hyperplastic and malignant epithelial cells from human prostate. J Urol 143: 167-171. 1990

397. Nagle RB, Ahmann FR, McDanicl KM, Paquin MI, Clark VA, Celniker $\Lambda$ : Cylokeratin characterization of human prostatic carcinoma and its derived cell lines. Cancer Res 47: 281-286, 1987

398. Pang S. Taneja S, Dardashti K, Cohan P, Kaboo R, Sokoloff M, Tso CL, deKernion JB, Bclldegrun AS: Prostate lissue specificity of the prostate-specifie antigen promoter isolated from a patient with prostate cancer. Human Gene Therapy 6: $1417-1426,1995$

399. Isracli RS, Powell Cl, Corr JG, Fair WR, Heston WD: Expression of the prostate-specific membrane antigen. Cancer Rcs 54: 1807-1811. 1994

400. Kostenuik PJ, Sanchez-Sweatman O, Orr FW, Singh G: Bone cell matrix promotes the adhesion of human prostatic carcinoma cells via the $\alpha 2 \beta 1$ integrin. Clin Exp Metastasis $14: 19-26,1996$

401. Dedhar S, Jewell K, Rojiani M, Gray V: The receptor for the basement membrane glycoprotein cntactin is the intcgrin alpha 3/beta 1. J Biol Chem 267: 18908-18914, 1992

402. Rokhlin OW, Cohen MB: Expression of cellular adhesion molecules on human prostate tumor cell lines. Prostate 26: 205-212, 1995

403. Fan K: Heterogencous subpopulations of human prostatic adenocarcinoma cells: potcintial uselumess of P21 protsin as a predictor for bone metastasis. J Urol 139: 318-322, 1988

Addess for offprints: Dr El-Nasir Lalani. Department of Histopathology, Royal Postgraduate Medical School, Hammersmith I lospital, Du Cranc Road, London W12 ONN, UK 